\title{
The Sierra de Cachi (Salta, NW Argentina): geological evidence about a Famatinian retro-arc at mid crustal levels
}

\author{
F. D. Hongn ${ }^{1}$, J. M. Tubía2*, J. J. Esteban², A. Aranguren², N. Vegas², S. Sergeev², \\ A. Larionov ${ }^{3}$, M. Basei ${ }^{4}$ \\ ${ }^{I} I B I G E O$, Conicet-Universidad Nacional de Salta, Av. Bolivia 5150, 4400-Salta, Argentina. \\ ${ }^{2}$ Departamento de Geodinámica, Universidad del País Vasco (UPV/EHU), Apartado 644, 48080-Bilbao, Spain. \\ 3 Centre of Isotopic Research, VSEGEI, 199106 St. Petersburg, Russia. \\ 4 Instituto de Geociencias, Universidade de São Paulo, São Paulo, Rua do Lago 562, SP, Brazil
}

e-mail addresses:fhongn@conicet.gov.ar(F.D.H.); jm.tubia@ehu.es (J.M.T., *Corresponding author); jj.esteban@ehu.es (J.J.E.); goparira@lg.ehu.es (A.A.); nestor.vegas@ehu.es(N.V.); Sergey_Sergeev@vsegei.ru (S.S.); cirvsg@vsegei.sp.ru(A.L.); baseimas@usp.br (M.B.)

Received: 1 October 2013 / Accepted: 5 May 2014 / Available online: 25 June 2014

\begin{abstract}
The Cachi mountain ranges, located in Salta (NW Argentina), form an inlier where Neoproterozoic and Paleozoic materials of the Andes crop out in a plutono-metamorphic dome surrounded by Mesozoic and Cenozoic sedimentary rocks. The pre-Mesozoic rocks record a regional metamorphism of low pressure and high temperature conditions, which reached partial melting conditions and was coeval with the intrusion of sheeted granite and trondhjemite plutons. The metamorphic evolution and the emplacement of the plutons took place in an extensional tectonic setting. New U-Pb zircon dating by TIMS and SHRIMP methods yields similar ages for the migmatization (479.7 $\pm 3.5 \mathrm{Ma})$ and the emplacement of granites $(472.1 \pm 11 \mathrm{Ma})$, constraining the extensional event to Early Ordovician times. We also report the finding of gabbro boulders, which also yield a similar U-Pb SHRIMP zircon age of $477.5 \pm 3.9 \mathrm{Ma}$. So, we propose that the extensional event recognized in Sierra de Cachi took place in a retro-arc setting linked to the Famatinian subduction along the western border of Gondwana. The shortening produced by younger east-verging folds evidences the superposition of a compressional stress field, probably related with the Ocloyic orogeny (Middle/Late Ordovician-Devonian).
\end{abstract}

Keywords: U-Pb geochronology, Famatinian retro-arc, Cachi ranges, Argentina

Resumen

En la Sierra de Cachi, situada en Salta (NO de Argentina), afloran rocas neoproterozoicas y paleozoicas de los Andes en un domo plutono-metamórfico flanqueado por rocas sedimentarias mesozoicas y cenozoicas. Estas rocas registran un metamorfismo de alta temperatura y baja presión, que alcanzó condiciones de fusión parcial y fue coetáneo del emplazamiento de plutones de granitos y trondhjemitas. El metamorfismo y el emplazamiento de los plutones se produjo en condiciones extensionales. Nuevos análisis de U-Pb en zircones, por los métodos TIMS y SHRIMP, proporcionan edades similares para la migmatización $(479,7 \pm 3,5 \mathrm{Ma})$ y el emplazamiento de los granitos $(472,1 \pm 11 \mathrm{Ma})$, acotando el evento extensional al Ordovícico Inferior. También describimos el hallazgo de bloques de gabros que dan una edad U-Pb SHRIMP en circones semejante, de 477,5 \pm 3,9 Ma. Por lo tanto, se propone que el evento extensional descrito en la Sierra de Cachi tuvo lugar en una zona de retro-arco asociada a la subducción famatiniana del borde occidental de Gondwana. El acortamiento producido por los pliegues más jóvenes vergentes al E refleja la superposición de un campo de esfuerzos compresivos, probablemente relacionados con la orogenia Oclóyica (Ordovícico Medio/Superior-Devónico).

Palabras clave: geocronología U-Pb, retro-arco famatiniano, Sierra de Cachi, Argentina

\section{Introduction}

To a large extent the geology of the Central Andes has been driven by subduction from Paleozoic times onwards (Mpo- dozis and Kay, 1999). The trail left by subduction processes in orogenic belts may include geological evidence as different as magmatic arcs, back-arc basins or suture zones with related high-pressure metamorphic rocks if subduction ends 
in collision of continental plates. However, the expression of the protracted subduction in the Central Andes is almost limited to magmatic arcs. Depending on the age, the preservation of these arcs is quite diverse. For example, in northern Chile and Argentina there are four continuous Liasic to Cenozoic magmatic arc systems so well preserved that allow recognize different angles of convergence obliqueness between the Nazca and South-America plates (Scheuber and Reutter, 1992). In contrast, older magmatic arcs are dismembered, poorly known and still lack time constraints relevant to correlate tectonic events between regions and hence to establish accurate reconstructions of the Paleozoic geodynamics.

In this paper, we present new geochronological results of migmatite and granite rocks from the Sierra de Cachi, located in the Calchaquí Valleys at Salta, NW Argentina (Fig. 1a). The first systematic U-Pb analyses of monazite and zircon from plutons of the Calchaquí Valleys (Lork et al., 1989; Lork and Bahlburg, 1993) confirmed an Early Ordovician age for their emplacement, in line with previous $\mathrm{K} / \mathrm{Ar}$ and $\mathrm{Rb} /$ Sr data from the Quilmes range (Rapela, 1976; Toselli et al., 1978). Further geochronological works reinforce the notion of a magmatic and metamorphic peak at around 480-460 Ma in the basement inliers scattered along the western border of the Calchaquí Valley and in the eastern Puna, between latitudes $24^{\circ}$ and $27^{\circ} \mathrm{S}$ (Haschke et al., 2005; Viramonte et al., 2007; Einhorn, 2010; Sola et al., 2010; Hauser et al., 2011).

The tectonic setting of the Lower Paleozoic rocks in NWArgentina is well constrained for the Ordovician sedimentary basins and coeval magmatic rocks, which in general are thought as back-arc or retro-arc basins associated with Early Ordovician extension followed by a contractional stage with related foreland basins from Middle Ordovician times (Bahlburg and Hervé, 1997; Astini, 2008 Moya, 2008; Zimmermann et al., 2010 among others). In contrast, the relationships between the magmatism and metamorphism, as well as the tectonic setting linked to these processes remain as pending questions in older and strongly deformed domains such as those that compose the igneous-metamorphic complexes of the Puna-Calchaquí Valleys transition zone, where pre-Ordovician rocks host plutons mainly of Ordovician age. By combining new age data with field and petrographic data, we will show that the metamorphic and magmatic evolution of the Sierra de Cachi is consistent with continental extension at mid crustal, associated with the development of a retro-arc during the Famatinian orogeny. We also report the finding of boulders of mafic rocks - gabbro and diorite - which yield the same crystallization age than the metamorphic and granite samples and would attest for the involvement of the mantle during the opening of the retro-arc.

\subsection{Regional setting}

In the Puna and Andean Eastern Cordillera of northwestern Argentina, many mountain ranges, displaying N-S elongation, are inliers where Neoproterozoic and Lower Paleozoic rocks crops out bounded by sedimentary deposits of Mesozoic and Cenozoic age. The N-S arrangement of such inliers is mainly due to the activity of Paleogene and Neogene Andean faults (Fig. 1a), which reflect the overall E-W convergence between the Nazca and South-America plates. This study deals with one of such inliers, the Sierra de Cachi, belonging to the Eastern Cordillera and located along the western banks of the Calchaquí Valleys, $100 \mathrm{~km}$ to the west of Salta (NW Argentina; Fig. 1a). The oldest exposed rocks of the Sierra de Cachi, from now on named basement, consist of three main lithological units, referred to as Puncoviscana, La Paya and Cachi formations. The basement is surrounded by Mesozoic and Cenozoic sedimentary deposits, which are concentrated along the Luracatao and Calchaquí Valleys respectively. The southwestern corner of the study region includes the Oire Eruptive Complex, composed of granite and granodiorite of Lower Ordovician age (Lork and Bahlburg, 1993) (Fig. 1b).

The Puncoviscana Formation encompasses a thick and complex metaturbiditic sequence whose Neoproterozoic to Early Cambrian age is constrained by trace fossils, ages from detrital zircons and volcanic intercalations, and by the Early Cambrian intrusion of the Cañaní and Santa Rosa de Tastil granite batholiths (Bachman et al., 1987; Aceñolaza and Toselli, 2009; Hongn et al., 2010; Adams et al., 2011; Augustsson et al., 2011; Escayola et al., 2011). The study of the Puncoviscana Formation has fostered conflicting interpretations concerning the tectonic setting prevailing during its formation (Keppie and Bahlburg, 1999). This formation has been interpreted as: 1) Deposits along the western passive margin of the Pampia craton (Jezek et al., 1985; Do Campo and Ribeiro Guevara, 2005), 2) An aulacogenic basin between the Río de la Plata Craton and the Arequipa-Antofalla terrane (Aceñolaza and Toselli, 2009) or 3) A peripheral foreland basin (Keppie and Bahlburg, 1999; Kraemer et al., 1995; Zimmermann, 2005).

The Puncoviscana Formation is only affected by very-low to low grade metamorphism, while the La Paya Formation encompasses metamorphic rocks ranging from low-, medium- and high-grade schists up to migmatites (Aceñolaza et $a l .$, 1976). With regard to the origin of metamorphism of the La Paya Formation, two competing hypotheses have been proposed. It is interpreted as a contact metamorphism promoted by the intrusion of the trondhjemite plutons grouped in the Cachi Formation (Schön and Miller, 1990; Toselli, 1992; Méndez et al., 2006) or, alternatively, as a regional metamorphism linked to either crustal thinning in an extensional tectonic setting (Tubía et al., 2005, 2008) or to a convergent tectonic regime (Sola et al., 2010).

\section{Lithological composition and structural arrangement of the Sierra de Cachi}

Although slates are abundant locally, in the Cachi region the Puncoviscana Formation is dominated by a multi-layer sequence with alternating slates and metagreywackes that 


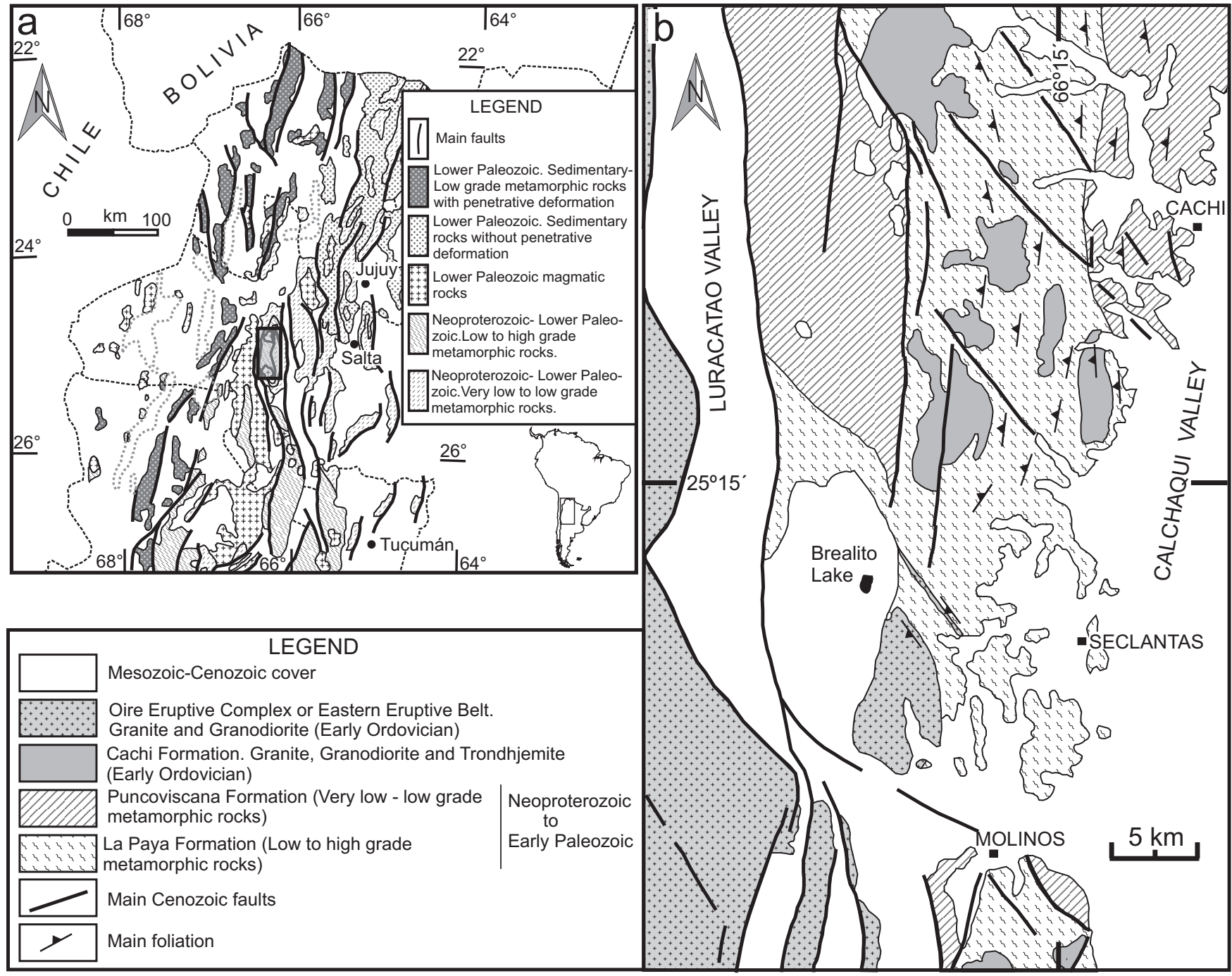

Fig. 1.- (a) Simplified map of the Neoproterozoic-Lower Paleozoic basement in Northwestern Argentina. The square indicates the location of the study area. (b) Sketch showing the main lithological units in the basement at the western border of the Calchaquí Valley, between $25^{\circ} 00^{\prime}$ and $25^{\circ} 30^{\prime} \mathrm{S}$.

preserve sedimentary structures, such as ripples and load casts (Fig. 2a). Only a rough cleavage can be recognized in the metagreywacke layers, while a pervasive slate cleavage is present in the slates (Fig. 2a). The cleavage dips around $50^{\circ}$ to the west (Fig. 1b) and is associated to asymmetric E-verging folds with interlimb angles between $40^{\circ}$ and $50^{\circ}$. This main slate cleavage almost obliterates an older cleavage associated to scarce folds with isoclinal geometry.

The Sierra de Cachi allows recognize a gradual transition from the Puncoviscana to the La Paya Formation (Fig. 1b). This transition is marked by the appearance of sparse and tiny neoblast of chlorite and rare andalusite in dotted slates, which are gradually replaced by medium- to coarse-grained schists where porphyroblasts of plagioclase, muscovite and cordierite are widespread and easily recognized to the naked eye. Neither garnet nor staurolite has been observed in the nearly 200 thin sections of metamorphic samples we have studied. The porphyroblasts commonly display random orientation, but within some deformed layers they define a good mineral lineation (Fig. 2b). Plagioclase porphyroblasts usually contain muscovite flakes whose orientation mimics the crystallographic structure of plagioclase (Fig. 3a), while the muscovite porphyroblasts are characterized by inclusions of sillimanite (Fig. 3b). Increasing metamorphism promotes partial melting processes, starting with the generation of small amount of melts concentrated in leucocratic veinlets (Fig. $2 c$ ) and ending in the widespread production of stromatic and diatexitic migmatites. The diatexites display granofelsic structures, defined by large grains of plagioclase and quartz with random orientation in a fine-grained matrix consisting of quartz, biotite and minor magnetite. Plagioclase contains muscovite inclusions displaying similar orientations to these observed in plagioclase porphyroblasts from schists (Fig. 3c). Magnetite-bearing cordieritites of probable restitic origin are fairly common in highly differentiated migmatites (Fig. 3d).

Compositional layering of sedimentary origin is found very often within the La Paya Formation, even under partial melting conditions (Fig. 2c). This layering looks like that ob- 

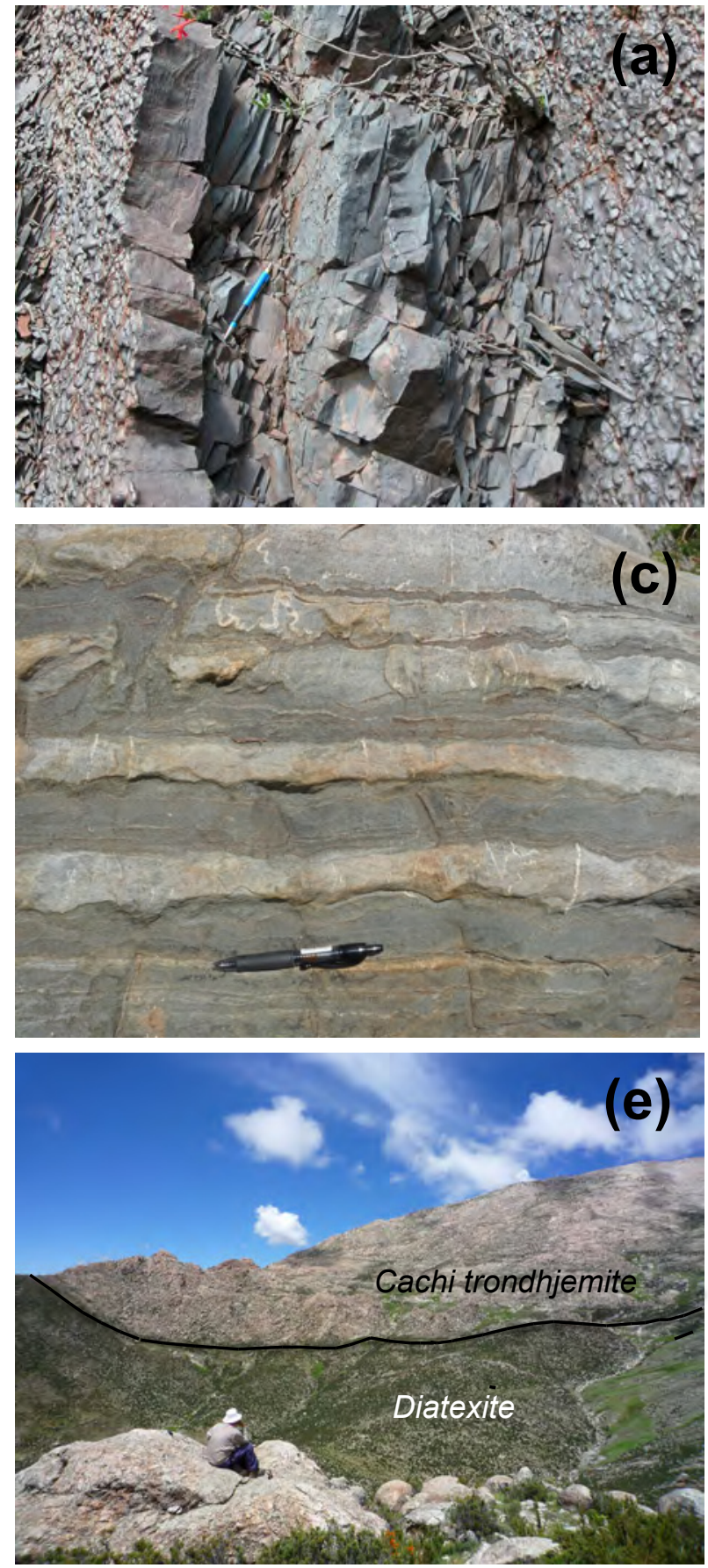
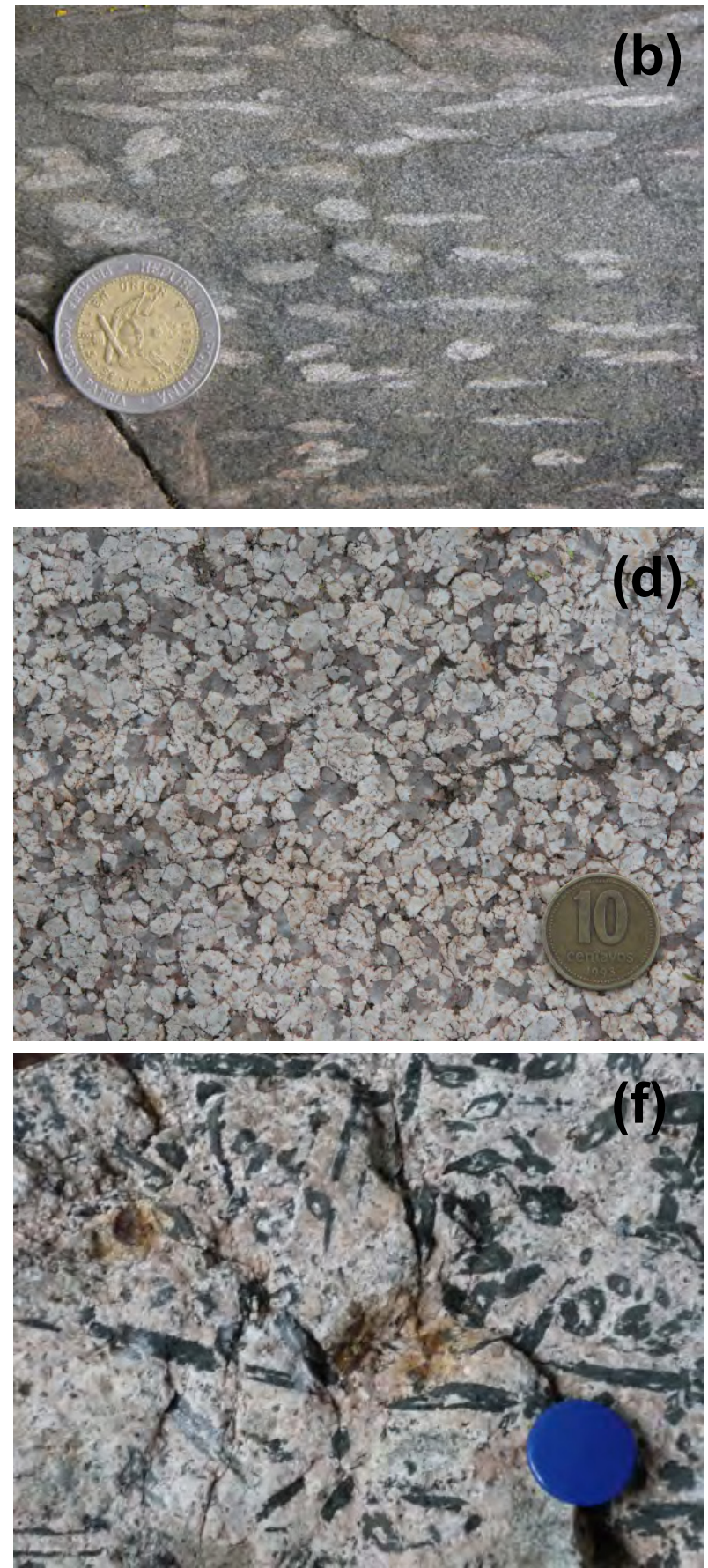

Fig. 2.- Field aspect of the main lithological formations of the Cachi mountain range. (a) Alternance of very-low grade metamorphic metapsamite and metapelite beds of the Puncoviscana Formation, showing the preservation of load cast in metapsamite. (b) Mineral lineation in andalusitebearing schists from the La Paya Formation. (c) Compositional layering of sedimentary origin preserved at high-grade metamorphic conditions associated to the generation of thin granite veins in the La Paya Formation. (d) Common equigranular microstructure defined by idiomorphic oligoclase and nearly equiaxial grains of quartz in a trondhjemite (Cachi Formation). (e) Basal contact between the Cachi trondhjemite and diatexitic country rocks. The flat-dipping contact reflects the sheeted shape of the granite pluton. (f) Porphyritic structure in a diorite boulder. The structure is defined by randomly oriented amphibole prisms in a finer-grained matrix with plagioclase and amphibole.

served in the Puncoviscana Formation (compare figures 2a and 2c). Altogether with the gradual increase of metamorphism from the Puncoviscana slates to the La Paya schists, the widespread preservation of metasedimentary layers in schists and migmatites indicates that the La Paya Formation is derived from the Puncoviscana Formation.
Three main arguments converge to indicate that the metamorphism took place in an extensional tectonic setting: 1) Mineral assemblages with cordierite and sillimanite/andalusite are consistent with high-temperature (HT) and lowpressure (LP) conditions, 2) The metamorphic zoning is characterized by a noticeable telescoping of isograds (Tubía et 

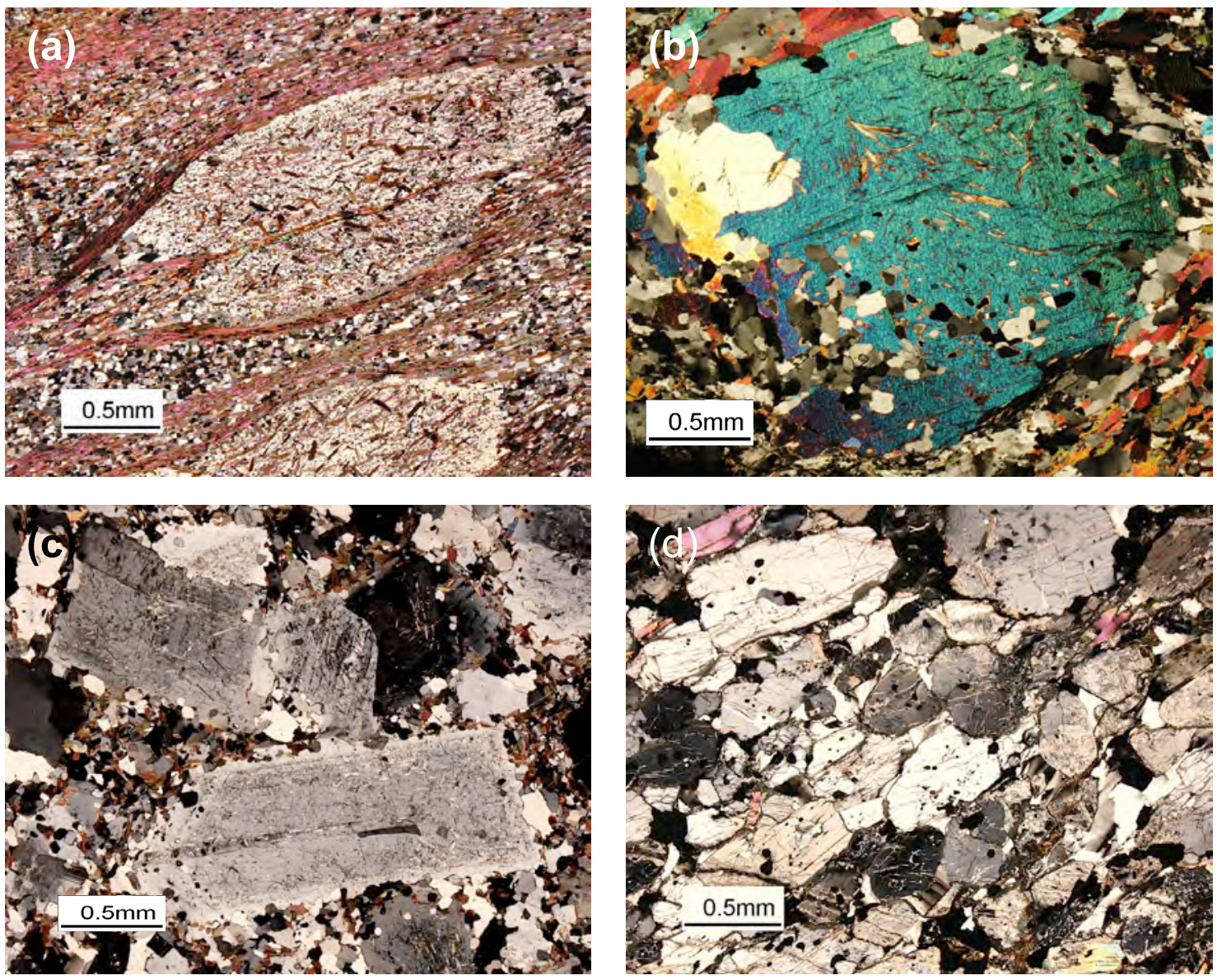

Fig. 3.- Photomicrographs of La Paya Formation metamorphic rocks. (a) Plagioclase porphyroblasts, in a cordierite-bearing schist, characterized by the presence of muscovite inclusions whose orientation mimics the crystallographic structure of the plagioclase. (b) Muscovite porphyroblasts with sillimanite inclusions. (c) Porphyroblastic microstructure in a diatexite. Plagioclase contains muscovite inclusions displaying similar orientations to those observed in plagioclase porphyroblasts from schists. (d) Magnetite-bearing cordieritite of restitic origin.

al., 2005, 2008) and 3) By places, the metamorphic zoning is affected by omissions of isograds produced by ductile shear zones. It is worth noting that the La Paya Formation is characterized by a reverse metamorphic zoning at the regional scale. This fact does not imply the existence of a primary inverted metamorphic gradient but it rather reflects deformation by E-verging folds (Hongn et al., 1999) later than the extensional deformation. An additional consequence of this late folding event is that the La Paya Formation rests over the Puncoviscana Formation everywhere (Fig. 1b).

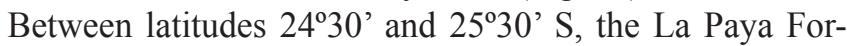
mation is punctuated by a set of granite plutons and associated pegmatites (Galliski, 1983a, b), referred to as Cachi Formation (Turner, 1964). The leucocratic plutons of the Cachi Formation can be grouped in two suites, depending on whether they consist of granodiorite-tonalite or trondhjemite. Trondhjemites are characterized by the presence of plagioclase crystals with muscovite inclusions (Fig. 4a) similar to those observed in plagioclase porphyroblasts of schists and migmatites from the La Paya Formation (see figures $3 \mathrm{a}$ and c). In contrast, the granite plutons contain crystals of potassic feldspar (Fig. 4b), which contain sillimanite inclusions very often (Fig. 4c). Medium- to coarse-grained rocks with equi- granular texture are dominant in the granite and trondhjemite plutons (Fig. 4a), which makes difficult the recognition of magmatic foliations to the naked eye (Fig. 2d). However, the interleaving of ribbons of metamorphic rocks helps to recognize internal layered structures consistent with the overall sheeted shape of each pluton. Regardless of its composition, all these plutons show similar structural features, as they are concordant with the foliation of the country rocks, display sheeted geometry (Fig. 2e), are deformed at HT conditions by extensional shear zones and the foliation of the country rocks outlines triple points around the tips of the plutons. Although previous works postulate a post-kinematic emplacement for these plutons (Galliski, 1983a; Toselli, 1992), we consider that these structural observations rather point to syn-kinematic emplacement during the extensional tectonic event. From all these plutons only the La Paya granite, emplaced in schists of medium-grade metamorphism, is surrounded by an aureole of contact metamorphism. The remaining plutons of the study region are emplaced in migmatite domains and do not show aureoles. The emplacement of the plutons took place before the late folding event according to the recognition of large folds in the Vallecito and Las Cabritas plutons (Hongn et al., 1999). 
We report the finding of diorite and gabbro boulders in Quaternary debris accumulated along the banks of several valleys located in the northern half of the study region. These rocks are more abundant nearby the Virgen de Los Cielos shrine (Fig. 9b). There, over an area of about $0.5 \mathrm{~km}^{2}$, the Quaternary deposits contain countless blocks of mafic rocks, mingled with cobbles of high-grade schist, migmatite and granite. The mafic boulders show great petrographic and textural variations. Most of them correspond to coarse-grained diorite and gabbro with phaneritic allotriomorphic texture (Fig. 4d). Composite boulders characterized by a magmatic layering defined by alternating coarse- and medium-grained layers are frequent, as also does the presence of doleritic dykes in gabbro. Finally, there are some rare but interesting boulders consisting of coarse-grained diorite with poikilitic megacrysts of amphibole that grew around leucocratic droplets (Fig. 2f) composed by plagioclase and quartz; such samples could result from mixing processes between mafic and acidic magmas. These observations suggest that: 1) The basic boulders come from a layered mafic pluton emplaced at shallow levels and, 2) The emplacements of the granite and gabbro plutons were coeval. We have dated a big boulder of gabbro to check the validity of the last point, as it is signifi- cant in order to discuss the heat source required to promote the metamorphism of the Cachi mountain range and to accurately constrain the geodynamic setting prevailing in this region during the Famatinian orogenic cycle.

\section{U-Pb geochronology of plutonic and metamorphic rocks}

Two trondhjemites and a granite were dated by Thermal Ionization Mass Spectrometry (TIMS) at the Centro de Pesquisas Geocronológicas (Geochronological Research Center) of IGc-USP (São Paulo, Brazil), following the standard procedures described in Basei et al. (1995). Besides, in situ $\mathrm{U}-\mathrm{Pb}$ analyses of zircons from three additional samples (migmatite, granite and gabbro) were performed on a Sensitive High Resolution Ion Microprobe (SHRIMP) at the Center of Isotopic Research at VSEGEI (Saint Petersburg, Russia). Tables 1 and 2 summarize the results of zircon-analyses by TIMS and SHRIMP methods, respectively.

The mineral separation routine for zircon starts with sample cleaning to eliminate altered portions and reduction to some centimeter-sized fragments with a jaw crusher. The material is then reduced to less than 60 mesh grain-size in a disc mill,
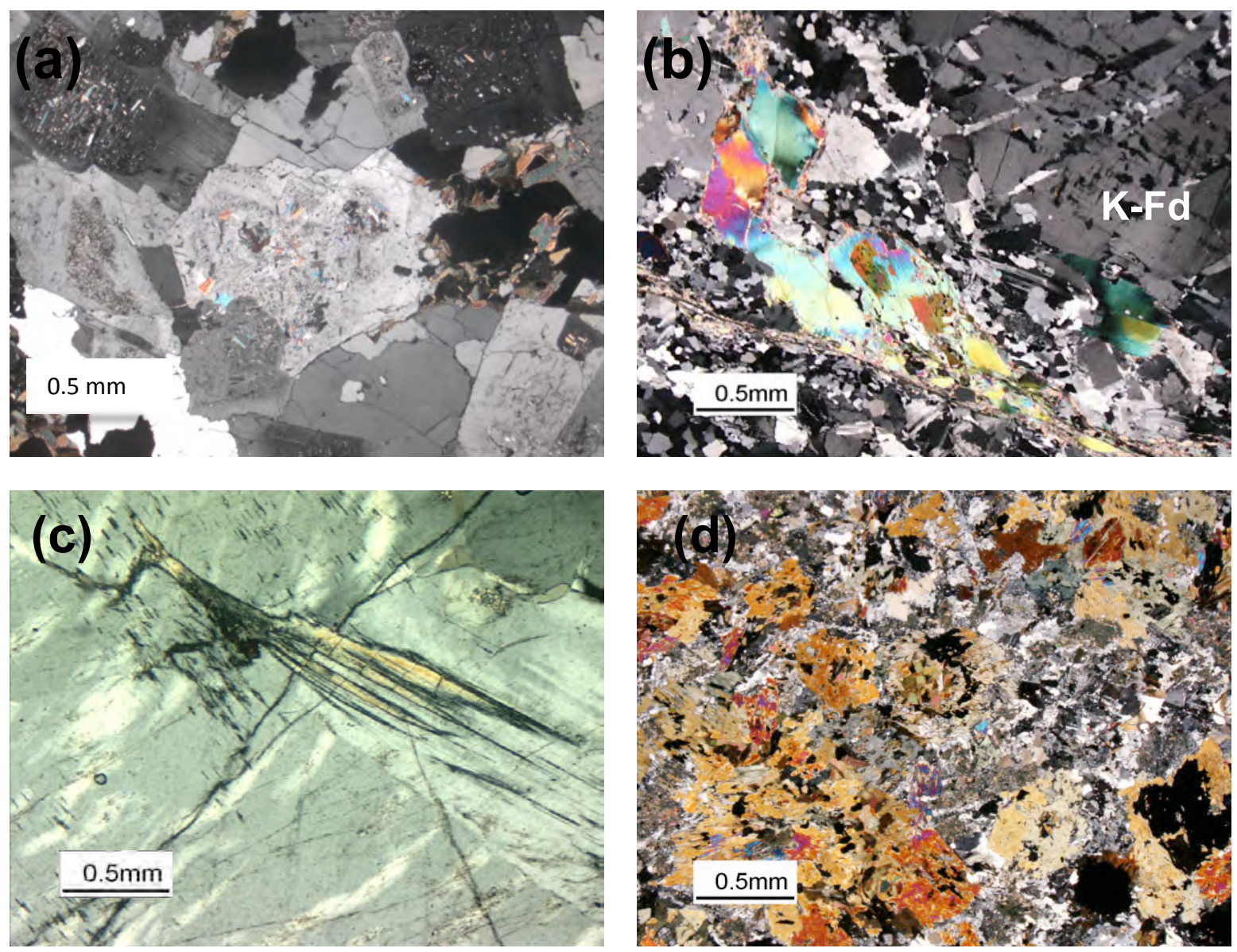

Fig. 4.- Photomicrographs of plutonic rocks. (a) Equigranular microstructure in a trondhjemite. Idiomorphic plagioclase crystals host numerous inclusions of muscovite. (b) Porphyroclast of potassic feldspar (K-Fd) in a S-C mylonite from the La Paya granite. (c) Inclusions of prismatic sillimanite in a crystal of potassic feldspar from the Las Cabritas granite. (d) Phaneritic allotriomorphic texture in a boulder of coarse-grained gabbro. 


\begin{tabular}{|c|c|c|c|c|c|c|c|c|c|c|}
\hline \multirow{2}{*}{ Name } & \multirow{2}{*}{$\begin{array}{c}\text { Weight } \\
\text { (mg) }\end{array}$} & \multicolumn{2}{|c|}{$\begin{array}{l}\text { Concentrations } \\
\text { (ppm) }\end{array}$} & \multicolumn{4}{|c|}{ Isotopic ratios (\% errors are $2 \sigma$ ) } & \multicolumn{3}{|c|}{ Age (Ma) } \\
\hline & & U & $\mathrm{Pb}$ & ${ }^{206} \mathrm{~Pb} / 204 \mathrm{U}$ & ${ }^{207} \mathrm{~Pb} / 235 \mathrm{U \#}$ & ${ }^{206} \mathrm{~Pb} / 238 \mathrm{~Pb}^{\#}$ & ${ }^{207} \mathrm{~Pb} /{ }^{206} \mathrm{~Pb}^{\#}$ & $\begin{array}{l}206 \mathrm{~Pb} / \\
238 \mathrm{U}\end{array}$ & $\begin{array}{l}{ }^{207} \mathrm{~Pb} / \\
{ }^{235} \mathrm{~Pb}\end{array}$ & $\begin{array}{l}{ }^{207} \mathrm{~Pb} / \\
206 \mathrm{~Pb}\end{array}$ \\
\hline \multicolumn{11}{|c|}{ Py-05-16 (El Alto trondhjemite) } \\
\hline 3165 & 0.00914 & 14.99 & 125.6 & 353.51 & $1.019650 \pm 1.96$ & $0.114166 \pm 1.84$ & $0.064776 \pm 0.66$ & 697 & 714 & 767 \\
\hline 3166 & 0.01017 & 29.67 & 262.4 & 174.83 & $0.781008 \pm 2.06$ & $0.087971 \pm 1.93$ & $0.064389 \pm 0.71$ & 544 & 586 & 754 \\
\hline 3168 & 0.01312 & 72.22 & 856.1 & 1004.95 & $0.653982 \pm 0.89$ & $0.081704 \pm 0.69$ & $0.058053 \pm 0.56$ & 506 & 511 & 532 \\
\hline 3169 & 0.00963 & 24.75 & 285.9 & 542.18 & $0.698502 \pm 1.21$ & $0.082193 \pm 1.13$ & $0.061636 \pm 0.42$ & 509 & 538 & 661 \\
\hline \multicolumn{11}{|c|}{ Py-01-06 (Vallecito monzogranite) } \\
\hline 2959 & 0.03100 & 34.3 & 404.2 & 1258.1 & $0.791762 \pm 0.65$ & $0.083832 \pm 0.63$ & $0.068499 \pm 0.17$ & 519 & 592 & 884 \\
\hline 3100 & 0.01251 & 18.56 & 236.0 & 1139.28 & $0.610467 \pm 0.80$ & $0.078670 \pm 0.60$ & $0.056280 \pm 0.52$ & 488 & 484 & 463 \\
\hline 3176 & 0.01069 & 29.59 & 342.1 & 746.15 & $0.713003 \pm 0.95$ & $0.085949 \pm 0.88$ & $0.060166 \pm 0.34$ & 532 & 547 & 610 \\
\hline 3178 & 0.01021 & 31.03 & 319.4 & 308.97 & $0.781742 \pm 1.68$ & $0.090597 \pm 1.62$ & $0.062582 \pm 0.40$ & 559 & 586 & 694 \\
\hline 3175 & 0.01087 & 31.81 & 317.5 & 205.86 & $0.693782 \pm 1.69$ & $0.084343 \pm 1.61$ & $0.059659 \pm 0.50$ & 522 & 535 & 591 \\
\hline 3179 & 0.01079 & 14.80 & 156.6 & 146.06 & $0.600394 \pm 3.48$ & $0.078168 \pm 3.38$ & $0.055707 \pm 0.72$ & 485 & 477 & 441 \\
\hline 3098 & 0.03550 & 45.39 & 332.5 & 117.16 & $0.665910 \pm 9.50$ & $0.086074 \pm 1.16$ & $0.056110 \pm 8.87$ & 532 & 518 & 457 \\
\hline \multicolumn{11}{|c|}{ Py-05-1 (Cachi trondhjemite) } \\
\hline 3119 & 0.03259 & 19.40 & 200.5 & 3645.56 & $0.889782 \pm 0.52$ & $0.092307 \pm 0.49$ & $0.069911 \pm 0.15$ & 569 & 646 & 926 \\
\hline 3122 & 0.03136 & 12.58 & 137.9 & 2167.29 & $0.716572 \pm 0.54$ & $0.085044 \pm 0.51$ & $0.061111 \pm 0.17$ & 526 & 549 & 643 \\
\hline 3152 & 0.0074 & 19.87 & 199.4 & 214.94 & $0.668197 \pm 2.32$ & $0.083599 \pm 2.11$ & $0.057970 \pm 0.91$ & 518 & 520 & 529 \\
\hline 3153 & 0.00425 & 22.39 & 241.4 & 3124.64 & $0.676700 \pm 1.78$ & $0.083419 \pm 1.67$ & $0.058834 \pm 0.58$ & 517 & 525 & 561 \\
\hline 3154 & 0.00356 & 30.77 & 338.1 & 226.76 & $0.637325 \pm 2.98$ & $0.080518 \pm 2.72$ & $0.057407 \pm 1.17$ & 499 & 501 & 507 \\
\hline
\end{tabular}

\# Radiogenic $\mathrm{Pb}$ corrected for blank and initial $\mathrm{Pb} / \mathrm{U}$ corrected for blank.

Table 1.- TIMS data from granite plutons of the La Cachi Formation.

classified in a Wilfley table and the heaviest mineral fraction is treated with bromoform (density $=2.89 \mathrm{~g} \mathrm{~cm}^{-3}$ ). This fraction is processed in a Frantz magnetic separator at $0.5 \mathrm{~A}$. The non-magnetic fraction is treated with methyl iodide (density $=3.3 \mathrm{~g} \mathrm{~cm}^{-3}$ ), and the heaviest minerals fraction is once more processed in the Frantz separator at 1.0 and $1.5 \mathrm{~A}$. When necessary, sulphides are eliminated with nitric acid $\left(\mathrm{HNO}_{3}\right)$. After washing, the material is once again processed in the Frantz separator and split in several zircon-rich magnetic fractions. The final purification of each fraction (preferably the least magnetic one) is carried out by hand picking under the stereomicroscope. At this step air-abrasion of a small quantity of zircon crystals, for TIMS analysis, is carried out using the same amount of pyrite for ca. 15 minutes to remove common $\mathrm{Pb}$ adsorbed at the crystal surface. Then, the fraction is washed again with hot $\mathrm{HNO}_{3}(50 \%)$ to remove pyrite and then with milli-Q water in an ultrasound bath.

\subsection{U-Pb TIMS: procedure and results.}

The weight of each zircon fraction is obtained by the volume/density ratio, after estimation of the volume of crystals under the stereomicroscope. After weighting, washing with $\mathrm{HNO}_{3}(50 \%)$ and milli-Q water in the ultrasound bath removes possible organic material. The dissolution of zircon crystals is carried out with the addition of $\mathrm{HF}$ and $\mathrm{HNO}_{3}$ in Teflon micro-bombs. A ${ }^{205} \mathrm{~Pb} /{ }^{235} \mathrm{U}$ spike is also added. A set of 15 micro-bombs arranged in a metal jacket is left for three days in a stove at $200{ }^{\circ} \mathrm{C}$. Then, the $\mathrm{HF}$ is evaporated and $\mathrm{HCl}$ $(6 \mathrm{~N})$ is added. The micro-bombs rest in a stove for 24 hours. $\mathrm{U}$ and $\mathrm{Pb}$ are concentrated and purified by passing the solution through an anionic exchange resin column. The solution enriched in $\mathrm{U}$ and $\mathrm{Pb}$ is, after addition of phosphoric acid, evaporated until the formation of a micro-drop. The drop is deposited in a rhenium filament and the isotopic composition is determined with a Finnigan MAT 262 solid source mass spectrometer. After reduction of the data (PBDAT), the results are plotted in appropriate diagrams using the software Isoplot/Ex (Ludwig, 2003).

A number of zircons large enough to split them into fractions with different magnetic susceptibility were separated from each sample. The analyzed crystals were selected under the stereomicroscope from the least magnetic fractions. The crystals are sub-idiomorphic, with well-defined faces and edges and length/width ratio between 2 and 3. In general, the grains are double terminated, transparent and with rare inclusions, bulbs or fractures. Zircon grain with inherited cores were avoided whenever possible.

A total of 16 zircon fractions were analyzed; 5 corresponding to the Cachi trondhjemite (Py-05-1), 7 to the Vallecito 

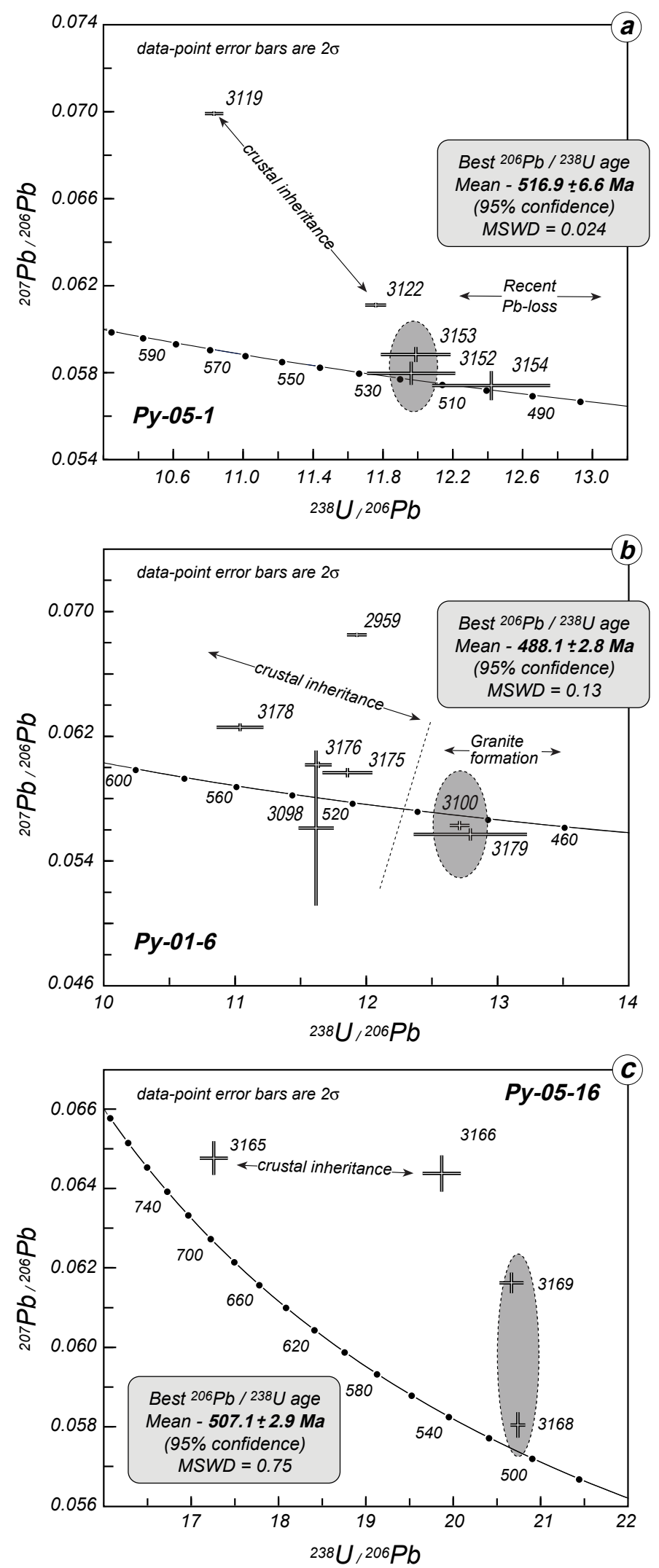

Fig. 5.- U-Pb, TIMS age determinations from the Cachi trondhjemite (sample Py-05-1), Vallecito granite (sample Py-01-6) and El Alto trondhjemite (sample Py-05-16). Sample locations are displayed in figure $9 b$. granite (Py-01-6) and 4 from the El Alto trondhjemite (Py05-16). The results are listed in table 1 . The high ${ }^{206} \mathrm{~Pb} /{ }^{204} \mathrm{~Pb}$ values show that there is no contamination by common ${ }^{204} \mathrm{~Pb}$. The Tera-Wasserburg diagrams show the discordance among the fractions (Fig. 5). The representative ages were obtained by the weighed average of ${ }^{206} \mathrm{~Pb} /{ }^{238} \mathrm{U}$ ages, taking into account the internal concordance among the various analyzed fractions for each sample.

Regarding the Cachi trondhjemite (Fig. 5a), fractions 3152 and 3153 yield an age of $516.9 \pm 6.6 \mathrm{Ma}$ ( $95 \%$ confidence / MSWD - 0.024). Fraction 3119 is the most discordant, this fact being in part explained by crustal inheritance. On the other hand, fraction 3154 yielded a younger ${ }^{206} \mathrm{~Pb} /{ }^{238} \mathrm{U}$ age, due to possible $\mathrm{Pb}$ loss. The analyses from the Vallecito granite (Fig. 5b) result in an age of $488.1 \pm 2.8 \mathrm{Ma}(95 \%$ confidence / MSWD - 0.13), which is consistent with the time span reported for the intrusion of granites in previous works (Haschke et al., 2005; Viramonte et al., 2007; Hauser et al., 2011; Einhorn, 2010). As for the previous sample, the most discordant fractions $(3098,3175,3176$ and 3178) were excluded from the calculations, as they yield older values consistent with a higher inherited component. Finally, fractions 3168 and 3169 yield an age of $507.1 \pm 2.9 \mathrm{Ma}$ for the El Alto trondhjemite (Fig. 5c) and in a similar way to the previous samples the effect of crustal inheritance is evident for the remaining two zircons fractions. These results evidence that the influence of inherited zircons is stronger in the trondhjemitic plutons since, for instance, the age of $517 \mathrm{Ma}$ obtained for the Cachi trondhjemite is closer to published ages of detrital zircons from the Puncoviscana Formation than to the crystallization of the plutons.

\subsection{U-Pb SHRIMP: methodology and results.}

After the routine mineral separation, zircon grains were sectioned approximately in half, polished and mounted in epoxy resin together with the TEMORA 1 and 91500 reference zircons. Cathodoluminescent (CL) images of the selected zircons reveal complex zoned patterns characterized by thin rims over either irregular/abraded (detrital) or idiomorphic (magmatic) cores. Such CL images thereby define target areas within the zircons (Fig. 6).

The results (Table 2) were obtained with a secondary electron multiplier in peak-jumping mode following the procedure described by Williams (1998) and Larionov et al. (2004). A primary beam of molecular oxygen was employed to bombard zircon in order to extract secondary ions. A $70 \mu \mathrm{m}$ Kohler aperture allowed focusing of the primary beam so that the ellipse-shaped analytical spot had a size ca. $25 \mu \mathrm{m} \times 20 \mu \mathrm{m}$, and the corresponding ion current was $5 \mathrm{nA}$. The sputtered secondary ions were accelerated at $10 \mathrm{kV}$. The $80 \mu \mathrm{m}$ wide slit of the secondary ion source, in combination with a $100 \mu \mathrm{m}$ multiplier slit, allowed mass-resolution $\mathrm{M} /$ $\Delta \mathrm{M} \geq 5000$ ( $1 \%$ valley); thus, all the possible isobaric interferences were resolved. One minute rastering over a rectan- 

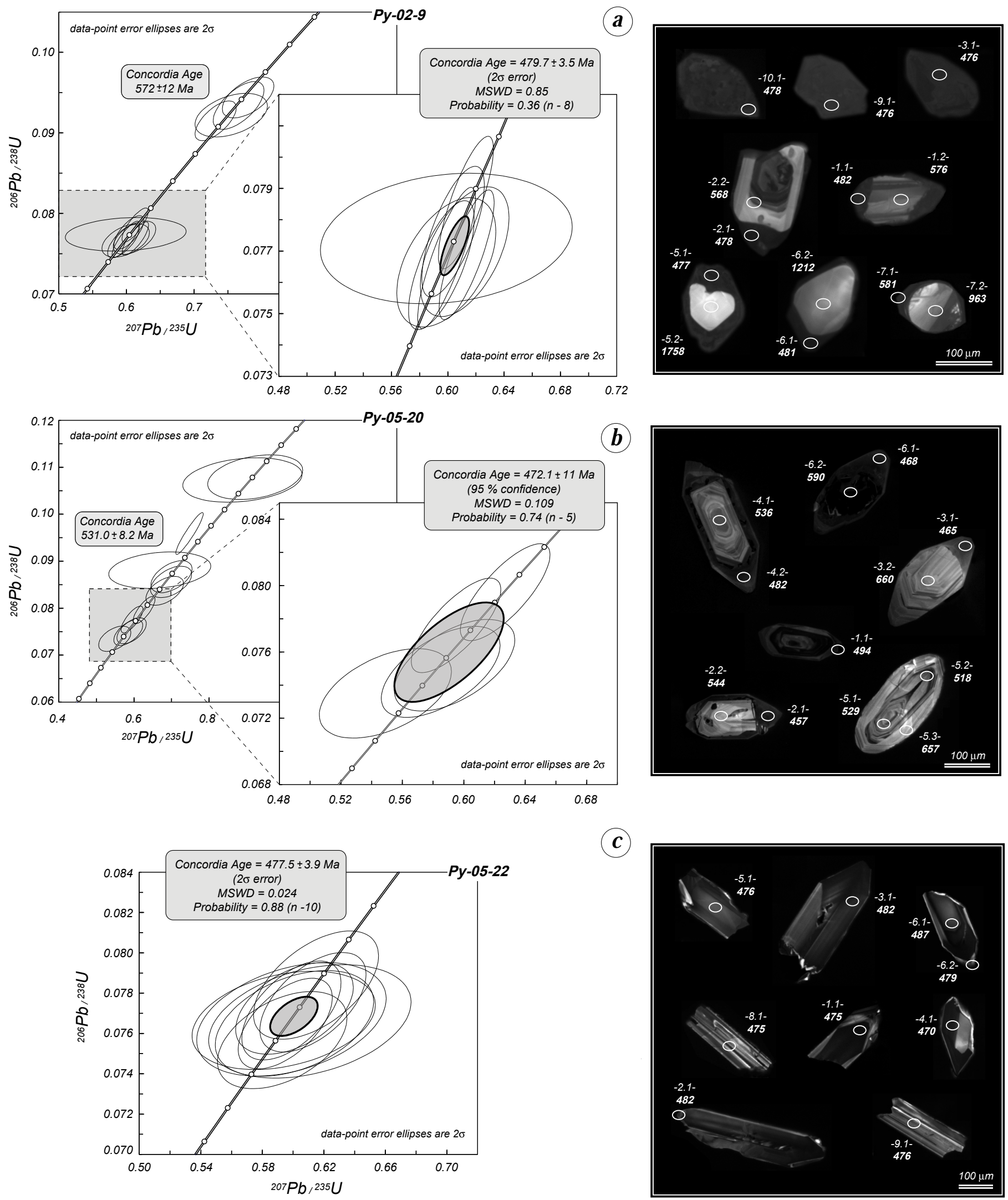

Fig. 6.- Tera-Wasserburg diagrams for analyzed zircons and representative cathodoluminescense images. (a) Sample Py-02-9 (La Paya granite). (b) Sample Py-05-20 (migmatite from the La Paya Formation). (c) Sample Py-05-22 (gabbro boulder). In each cathodoluminiscence image, ellipses on zircons show the spot locations with their corresponding ${ }^{206} \mathrm{~Pb} /{ }^{238} \mathrm{U}$ ages. Sample locations are displayed in figure $9 \mathrm{~b}$. 


\begin{tabular}{|c|c|c|c|c|c|c|c|c|c|c|c|c|c|}
\hline Spot Name & Info & $\begin{array}{c}{ }^{206} \mathrm{~Pb}_{\mathrm{c}} \\
(\%)\end{array}$ & $\begin{array}{c}U \\
(p p m)\end{array}$ & $\begin{array}{c}\text { Th } \\
\text { (ppm) }\end{array}$ & $\begin{array}{c}{ }^{232} \mathrm{Th} / \\
238 \mathrm{U}\end{array}$ & $\begin{array}{l}{ }^{206} \mathrm{~Pb}^{*} \\
(\mathrm{ppm})\end{array}$ & $\begin{array}{l}\text { (1) } \mathrm{Age}(\mathrm{Ma}) \\
{ }^{206} \mathrm{~Pb} /{ }^{238} \mathrm{U}\end{array}$ & $\begin{array}{l}\text { (1) } \mathrm{Age}(\mathrm{Ma}) \\
{ }^{207} \mathrm{~Pb} /{ }^{206} \mathrm{~Pb}\end{array}$ & $\begin{array}{c}\text { Dis. } \\
\%\end{array}$ & $\begin{array}{c}\text { (1) } \\
238 \mathrm{U} /{ }^{206} \mathrm{~Pb}^{*}\end{array}$ & $\begin{array}{c} \pm \\
(\%)\end{array}$ & $\begin{array}{c}\text { (1) } \\
{ }^{207} \mathrm{~Pb}^{*} / 206 \mathrm{~Pb}^{*}\end{array}$ & $\begin{array}{c} \pm \\
(\%)\end{array}$ \\
\hline \multicolumn{14}{|c|}{ Py-02-9 (Granite) } \\
\hline Py-02-9_3.1 & $c$ & 0.06 & 1954 & 4 & 0.002 & 129 & $475.5 \pm 5.1$ & $469 \pm 25$ & -1 & 13.06 & 1.1 & 0.05643 & 1.1 \\
\hline Py-02-9_9.1 & $c$ & 0.67 & 2233 & 18 & 0.008 & 148 & $476 \pm 5.2$ & $480 \pm 46$ & 1 & 13.04 & 1.1 & 0.0567 & 2.1 \\
\hline Py-02-9_5.1 & $r$ & 0.07 & 3436 & 8 & 0.002 & 227 & $476.9 \pm 5.6$ & $476 \pm 17$ & 0 & 13.02 & 1.2 & 0.0566 & 0.8 \\
\hline Py-02-9_2.1 & $r$ & 0.13 & 4940 & 26 & 0.005 & 327 & $477.5 \pm 5$ & $525 \pm 18$ & 10 & 13.01 & 1.1 & 0.05786 & 0.8 \\
\hline Py-02-9_10.1 & $r$ & 0.42 & 1663 & 8 & 0.005 & 110 & $478.1 \pm 5.2$ & $517 \pm 40$ & 8 & 12.99 & 1.1 & 0.0577 & 1.8 \\
\hline Py-02-9_6.1 & $r$ & 2.12 & 5908 & 52 & 0.009 & 402 & $480.6 \pm 5$ & $457 \pm 130$ & -5 & 12.91 & 1.1 & 0.0561 & 6.0 \\
\hline Py-02-9_1.1 & $r$ & 0.16 & 2972 & 11 & 0.004 & 199 & $481.9 \pm 5.1$ & $469 \pm 24$ & -3 & 12.88 & 1.1 & 0.05642 & 1.1 \\
\hline Py-02-9_4.1 & $c$ & 0.12 & 4301 & 9 & 0.002 & 291 & $487.5 \pm 5$ & $475 \pm 17$ & -2 & 12.73 & 1.1 & 0.05659 & 0.8 \\
\hline Py-02-9_8.1 & $r$ & 0.23 & 4823 & 16 & 0.003 & 380 & $564.7 \pm 5.9$ & $530 \pm 27$ & -6 & 10.92 & 1.1 & 0.05801 & 1.3 \\
\hline Py-02-9_2.2 & $c$ & 0.18 & 632 & 122 & 0.20 & 50.1 & $568.4 \pm 6.5$ & $582 \pm 57$ & 2 & 10.85 & 1.2 & 0.0594 & 2.6 \\
\hline Py-02-9_1.2 & $c$ & 0.06 & 577 & 182 & 0.33 & 46.3 & $575.7 \pm 7$ & $585 \pm 34$ & 2 & 10.7 & 1.3 & 0.05948 & 1.6 \\
\hline Py-02-9_7.1 & $r$ & 0.02 & 3674 & 18 & 0.005 & 298 & $581.5 \pm 6$ & $602 \pm 35$ & 4 & 10.59 & 1.1 & 0.05995 & 1.6 \\
\hline Py-02-9_7.2 & $c$ & 0.00 & 411 & 107 & 0.27 & 56.9 & $963 \pm 11$ & $1068 \pm 68$ & 11 & 6.206 & 1.2 & 0.075 & 3.4 \\
\hline Py-02-9_6.2 & $c$ & 0.07 & 242 & 94 & 0.40 & 43 & $1212 \pm 15$ & $1192 \pm 30$ & -2 & 4.835 & 1.4 & 0.0798 & 1.5 \\
\hline Py-02-9_5.2 & $c$ & -- & 97 & 94 & 1.01 & 26 & $1758 \pm 24$ & $1763 \pm 27$ & 0 & 3.19 & 1.6 & 0.1079 & 1.5 \\
\hline \multicolumn{14}{|c|}{ Py-05-20 (Migmatite) } \\
\hline Py-05-20_2.1 & $r$ & 0.38 & 568 & 6 & 0.01 & 36.1 & $457.4 \pm 3.8$ & $379 \pm 63$ & -17 & 13.60 & 1.5 & 0.0542 & 2.8 \\
\hline Py-05-20_3.1 & $r$ & 0.20 & 530 & 4 & 0.01 & 34.1 & $465.2 \pm 6.9$ & $479 \pm 48$ & 3 & 13.36 & 1.5 & 0.0567 & 2.2 \\
\hline$P y=05-20 \_6.1$ & $r$ & 0.23 & 636 & 6 & 0.01 & 41.2 & $467.6 \pm 6.8$ & $502 \pm 50$ & 7 & 13.29 & 1.5 & 0.0573 & 2.3 \\
\hline$P y=05-20 \_4.2$ & $r$ & 0.04 & 585 & 6 & 0.01 & 39.0 & $481.8 \pm 7.1$ & $438 \pm 29$ & -9 & 12.89 & 1.5 & 0.05565 & 1.3 \\
\hline Py-05-20_1.1 & $r$ & 0.15 & 839 & 126 & 0.15 & 57.4 & $493.5 \pm 7.1$ & $499 \pm 27$ & 1 & 12.57 & 1.5 & 0.0572 & 1.2 \\
\hline Py-05-20_5.2 & $c$ & 0.20 & 396 & 216 & 0.56 & 28.5 & $518.2 \pm 7.6$ & $572 \pm 56$ & 10 & 11.95 & 1.5 & 0.0591 & 2.6 \\
\hline Рy-05-20_5.1 & $c$ & 0.32 & 267 & 200 & 0.77 & 19.7 & $529.3 \pm 8$ & $576 \pm 61$ & 9 & 11.68 & 1.6 & 0.0592 & 2.8 \\
\hline Py-05-20_4.1 & c & 0.24 & 274 & 194 & 0.73 & 20.5 & $536.3 \pm 8.3$ & $549 \pm 62$ & 2 & 11.53 & 1.6 & 0.0585 & 2.8 \\
\hline Py-05-20_2.2 & $c$ & 1.07 & 126 & 42 & 0.35 & 9.6 & $544.0 \pm 9.4$ & $416 \pm 180$ & -24 & 11.35 & 1.8 & 0.0551 & 8.1 \\
\hline Py-05-20_6.2 & c & 0.01 & 4836 & 1991 & 0.43 & 398.0 & $590.0 \pm 11$ & $474 \pm 16$ & -20 & 10.43 & 1.9 & 0.05655 & 0.72 \\
\hline Рy-05-20_5.3 & $r$ & 1.01 & 200 & 146 & 0.76 & 18.6 & $657.0 \pm 11$ & $607 \pm 150$ & -8 & 9.31 & 1.8 & 0.0601 & 7.1 \\
\hline Py-05-20_3.2 & $\mathrm{c}$ & 0.54 & 97 & 127 & 1.35 & 9.1 & $660.0 \pm 11$ & $676 \pm 110$ & 2 & 9.27 & 1.8 & 0.0621 & 5.4 \\
\hline \multicolumn{14}{|c|}{ Py-05-22 (Diorite) } \\
\hline$P y=05-22 \_1.1$ & $c$ & 0.10 & 747 & 1945 & 2.69 & 49.1 & $475.2 \pm 5.4$ & $470 \pm 37$ & -1 & 13.07 & 1.2 & 0.0565 & 1.7 \\
\hline Py-05-22_2.1 & $b$ & 0.00 & 420 & 631 & 1.55 & 28 & $481.5 \pm 5.9$ & $503 \pm 42$ & 4 & 12.90 & 1.3 & 0.0573 & 1.9 \\
\hline$P y=05-22 \_3.1$ & $c$ & 0.13 & 592 & 1393 & 2.43 & 39.3 & $479.6 \pm 5.6$ & $469 \pm 52$ & -2 & 12.95 & 1.2 & 0.0564 & 2.3 \\
\hline$P y-05-22 \_4.1$ & $c$ & 0.23 & 552 & 1068 & 2.00 & 36 & $470.2 \pm 5.9$ & $484 \pm 57$ & 3 & 13.21 & 1.3 & 0.0568 & 2.6 \\
\hline$P y-05-22 \_5.1$ & $c$ & 0.18 & 196 & 237 & 1.25 & 12.9 & $476.2 \pm 7.1$ & $479 \pm 87$ & 1 & 13.04 & 1.5 & 0.0567 & 3.9 \\
\hline$P y-05-22 \_6.1$ & $c$ & 0.00 & 344 & 356 & 1.07 & 23.1 & $486.6 \pm 6.8$ & $488 \pm 49$ & 0 & 12.75 & 1.4 & 0.0569 & 2.2 \\
\hline$P y=05-22 \_6.2$ & $b$ & 0.00 & 568 & 1073 & 1.95 & 37.6 & $479 \pm 5.8$ & $466 \pm 41$ & -3 & 12.96 & 1.3 & 0.0563 & 1.8 \\
\hline Py-05-22_7.1 & $c$ & 0.44 & 531 & 1329 & 2.59 & 35.1 & $476.1 \pm 5.9$ & $462 \pm 86$ & -3 & 13.04 & 1.3 & 0.0562 & 3.9 \\
\hline$P y-05-22 \_8.1$ & $c$ & 0.23 & 324 & 45 & 0.14 & 21.4 & $475 \pm 6.5$ & $493 \pm 70$ & 4 & 13.08 & 1.4 & 0.0570 & 3.2 \\
\hline Py-05-22_9.1 & $c$ & 0.43 & 296 & 382 & 1.33 & 19.6 & $475.7 \pm 6.8$ & $524 \pm 90$ & 10 & 13.05 & 1.5 & 0.0578 & 4.1 \\
\hline
\end{tabular}

Table 2.- U, Th and Pb SHRIMP data for zircons in metamorphic and plutonic rocks from the Cachi range. In bold, the results that define an average age of $477.5 \pm 2.4 \mathrm{Ma}$ (see also Fig. 8).

gular area of ca. $65 \mu \mathrm{m} \times 50 \mu \mathrm{m}$ was employed before each analysis in order to remove the gold coating and any possible surface contamination by $\mathrm{Pb}$.

The following ion species were measured in sequence: ${ }^{196}\left(\mathrm{Zr}_{2} \mathrm{O}\right)-^{204} \mathrm{~Pb}$-background (ca. 204 AMU) ${ }^{206} \mathrm{~Pb}-{ }^{207} \mathrm{~Pb}-$ ${ }^{208} \mathrm{~Pb}-{ }^{238} \mathrm{U}-248 \mathrm{ThO}-{ }^{254} \mathrm{UO}$ with integration time ranging from 2 to $14 \mathrm{~s}$. Seven cycles for each analyzed spot were acquired. Apart from 'unknown' zircons, each fourth measurement was carried out on the zircon $\mathrm{Pb} / \mathrm{U}$ standard TEMORA
1 , which has an accepted ${ }^{206} \mathrm{~Pb} /{ }^{238} \mathrm{U}$ age of $416.75 \pm 0.24 \mathrm{Ma}$ (Black et al., 2003). The 91500 zircon standard, with U concentration of $81.2 \mathrm{ppm}$ and ${ }^{206} \mathrm{~Pb} /{ }^{238} \mathrm{U}$ age of $1062 \mathrm{Ma}$ (Wiedenbeck et al., 1995) was applied as the "U-concentration" standard. The data collected were then processed with the SQUID 1.02 (Ludwig, 2003) and Isoplot/Ex 3.00 (Ludwig, 2003) software, using the decay constants of Steiger and Jäger (1977). The common lead correction was done on the basis of measured ${ }^{204} \mathrm{~Pb} /{ }^{206} \mathrm{~Pb}$ and modern (i.e. $\left.0 \mathrm{Ma}\right) \mathrm{Pb}$ 


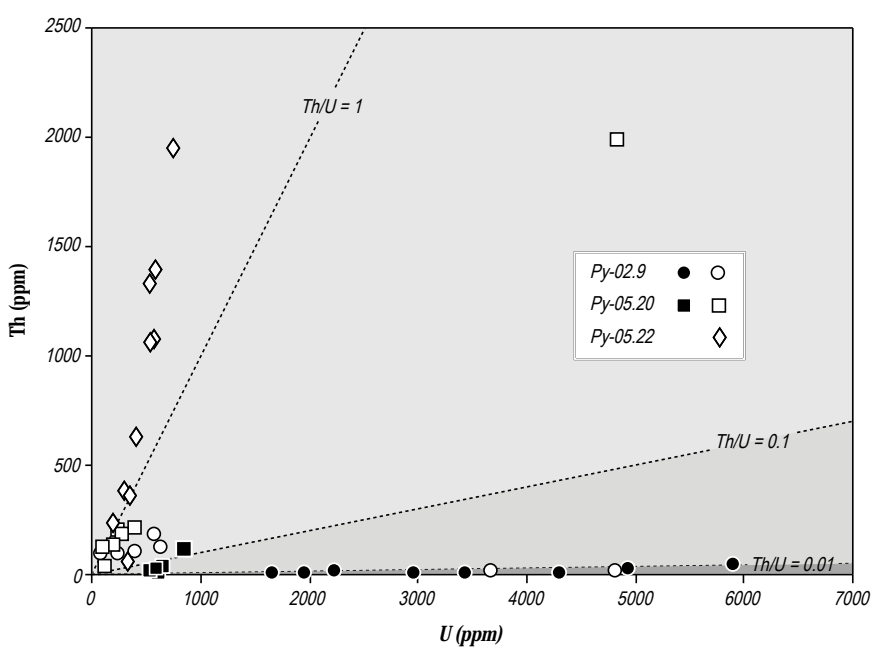

Fig. 7.- Th vs U content plot or zircons from analyzed samples. Black dots are those used to calculate the youngest concordia age.

isotope compositions, according to the model of Stacey and Kramers (1975).

The La Paya granite (sample Py-02-9: Table 2 and Fig. 6a) yields a concordia age of $479.7 \pm 3.5 \mathrm{Ma}(2 \sigma$ error; MSWD - 0.85), interpreted as the emplacement age of this anatectic granite. This result comes from U-rich $(\mathrm{Th} / \mathrm{U}<0.01$; Fig. 7) and dark luminescence zircons forming either homogeneous subidiomorphic grains or rims around detrital zircon cores (Fig. 6a). Similar emplacement ages have been proposed for other granite bodies from around the Cachi region (Lork and Bahlburg, 1993; Haschke et al., 2005; Einhorn, 2010). CLimages demonstrate the existence of rounded cores, which we interpret as inherited detrital zircons in agreement with their older, around $572 \mathrm{Ma}$, concordia age. Zircons extracted from a migmatite close to the SE contact with the El Hueco pluton (Table 2 and Fig. 6b: sample Py-05-20) yield concordia ages for the cores and the rims of $531 \pm 8.2 \mathrm{Ma}(2 \sigma$ error; MSWD - 0.76) and 472.1 $\pm 11 \mathrm{Ma}(2 \sigma$ error; MSWD - 0.109), respectively. The youngest concordia age comes from idiomorphic and dark luminescence external rims (Fig. 6b) developed over eroded/detrital zircon cores. These rims are characterized mainly by low $\mathrm{Th} / \mathrm{U}$ value (Fig. $7 ; \mathrm{Th} / \mathrm{U} \approx 0.01$ ). The core-age matches with those of detrital zircons in slates of the Puncoviscana formation from the Angosto de Rancagua site (Adams et al. 2011; Pearson et al., 2012). Otherwise, rim-age is consistent with the proposed age for the metamorphic climax (Sola et al., 2010) of samples from the Molinos Range (MR), located to the south of the Sierra de Cachi (Fig. 9b). Zircons from the gabbro (Py-05-22) have common igneous features like prismatic shape, oscillatory zoning, high $\mathrm{Th} / \mathrm{U}$ values (Fig. 7; Th/U > 0.15) and do not have inherited detrital cores (Fig. 6c). This sample yields an excellent $\mathrm{U}-\mathrm{Pb}$ SHRIMP concordia age of $477.5 \pm 3.9 \mathrm{Ma}(2 \sigma$ error $/ \mathrm{MSWD}$ -0.024 ; Table 2 and Fig. $6 c$ ). These observations are consistent with the magmatic origin of the zircon crystals and therefore date the crystallization age of the gabbro.

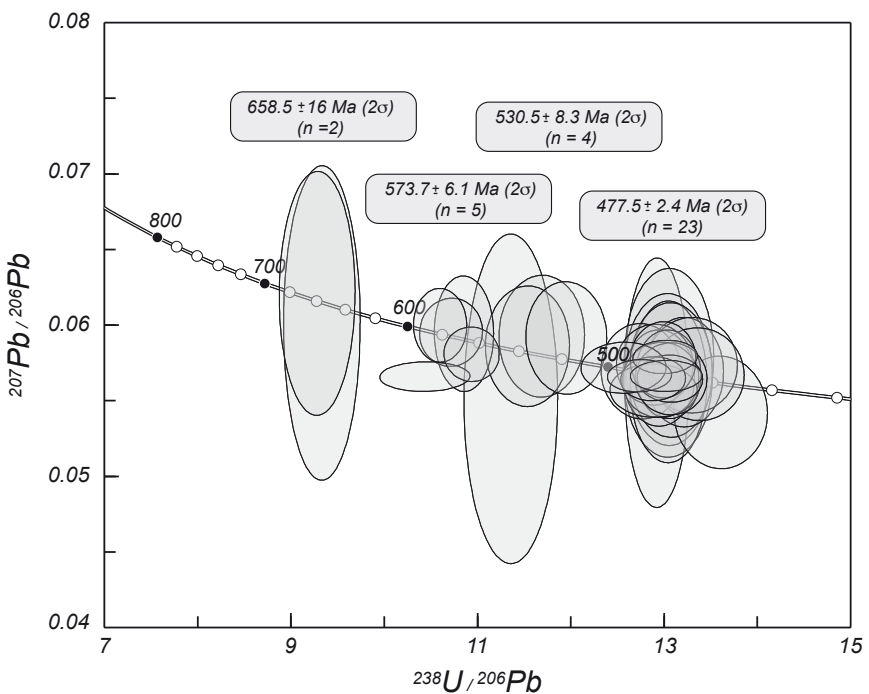

Fig. 8.- Tera-Wasserburg diagram for the U-Pb SHRIMP zircon-age data from the three analyzed samples.

On a Tera-Wasserburg diagram (Fig. 8) most of the analyses from the three samples define an average ${ }^{206} \mathrm{~Pb} /{ }^{238} \mathrm{U}$ age of $477.5 \pm 2.4 \mathrm{Ma}$ ( $2 \sigma$ error). This age is interpreted as the time of intrusion of basic magmas, coeval or slightly preceding the peak of the Early Ordovician metamorphism registered by the Puncoviscana and La Paya formations and by the generation of anatectic granites in the Cachi range. A few analyses grouping around the Concordia at $530.5 \pm 8.3 \mathrm{Ma}$, $573.7 \pm 6.1 \mathrm{Ma}$ and $658.5 \pm 16 \mathrm{Ma}$ are in line with previously reported ages for detrital zircons of the Puncoviscana Formation (Adams et al., 2011; Pearson et al., 2012).

\section{Discussion}

Available age data published until now in the Cachi and adjacent mountain ranges are compiled in figure 9 . We do not intend this contribution to be a review of all the geological implications of these geochronological data, but we would like to highlight two relevant points. The first point is that these data make evident some inconsistencies. For instance, the ages of detrital zircons from the Puncoviscana Formation around the Tastil batholith are younger than those dating the post-tectonic emplacement of the batholith as discussed by Hauser et al. (2011). These problems open a fan of interesting working hypotheses, among them the likely existence of unconstrained unconformities within the Puncoviscana Formation, which are out of the scope of this work. On the other hand, the compiled ages (Fig. 9) show two main age clusters, the older one between 509 and $536 \mathrm{Ma}$ and the younger between 452 and $485 \mathrm{Ma}$. The older values reflect inherited ages of the detrital sources of the Puncoviscana and La Paya (or equivalent) formations, while the younger cluster should be linked to the Ordovician metamorphism and magmatism (Lork et al., 1989; Lork and Bahlburg, 1993; Haschke et al., 2005; Viramonte et al., 2007; Sola et al., 2010; Einhorn, 2010; Adams et al., 2011; Hauser et al., 2011). These val- 
ues yield a time spam of nearly $30 \mathrm{Ma}$ for the magmatism and metamorphism in this sector of the Eastern Cordillera. It is worth noting that our new U-Pb SHRIMP zircon analyses (Fig. 6) constrain the thermal evolution of the region much better as they yield concordant ages, within the error limits, for the migmatization $(479.7 \pm 3.5 \mathrm{Ma})$ and the emplacement of granites $(472.1 \pm 11 \mathrm{Ma})$ and gabbros $(477.5 \pm 3.9 \mathrm{Ma})$. To our knowledge this is the first report of mafic rocks spatially related to, and coeval with, the HT-LP metamorphism and the granite magmatism in the Sierra de Cachi and neighbour regions, like the Molinos and Palermo ranges (Fig. 9). We interpret such basic boulders as part of the Paleozoic basement of the Sierra de Cachi, since a local provenance can be proposed for them based on their marked heterometry and poor roundness. Although we have not yet found gabbro outcrops, the location of the source area is fairly well constrained (see figure $9 \mathrm{~b}$ ) because the boulder-bearing valleys come together around 10 kilometres towards the NW, where the highest peak (Nevado de Cachi: 6380 metres) of the region is located. The presence of gabbroic rocks attests that the mantle was involved in the geodynamic process leading to the formation of the Cachi dome and suggests underplat-
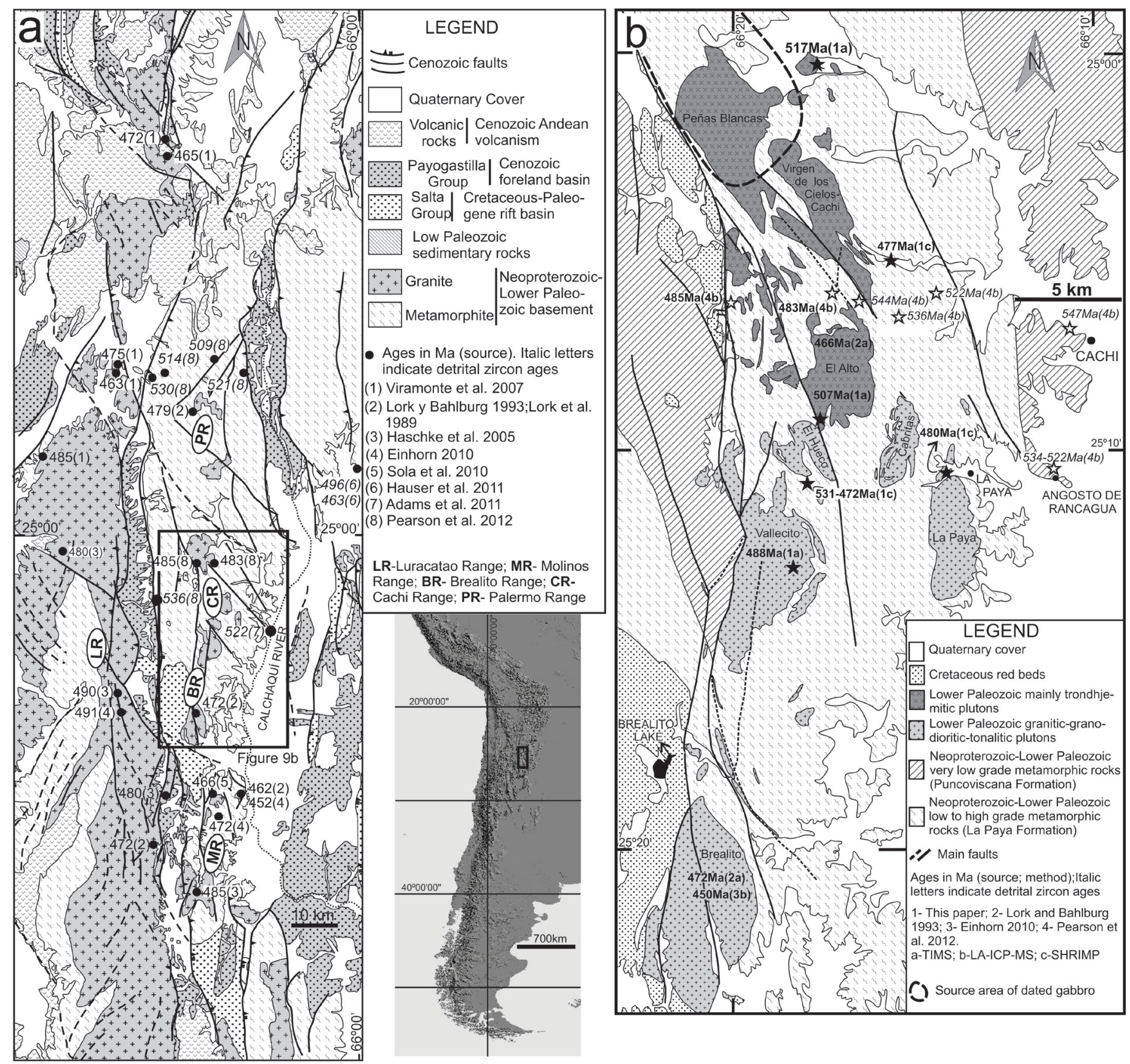

Fig. 9.- (a) Geological map with location of U-Pb ages on units of the Neoproterozoic-Lower Paleozoic basement in the western part of the eastern Puna eastern the Calchaquí Valleys, between $24^{\circ} 00^{\prime}$ and $25^{\circ} 55^{\prime}$ S. (b) Geological map of the Cachi mountain range and neighbouring areas between $25^{\circ} 00^{\prime}$ and $25^{\circ} 25^{\prime} \mathrm{S}$, showing location of Neoproterozoic-Lower Paleozoic U-Pb ages. Stars indicate precise location when available information makes it possible. Black stars: This paper. White stars: Other authors. 


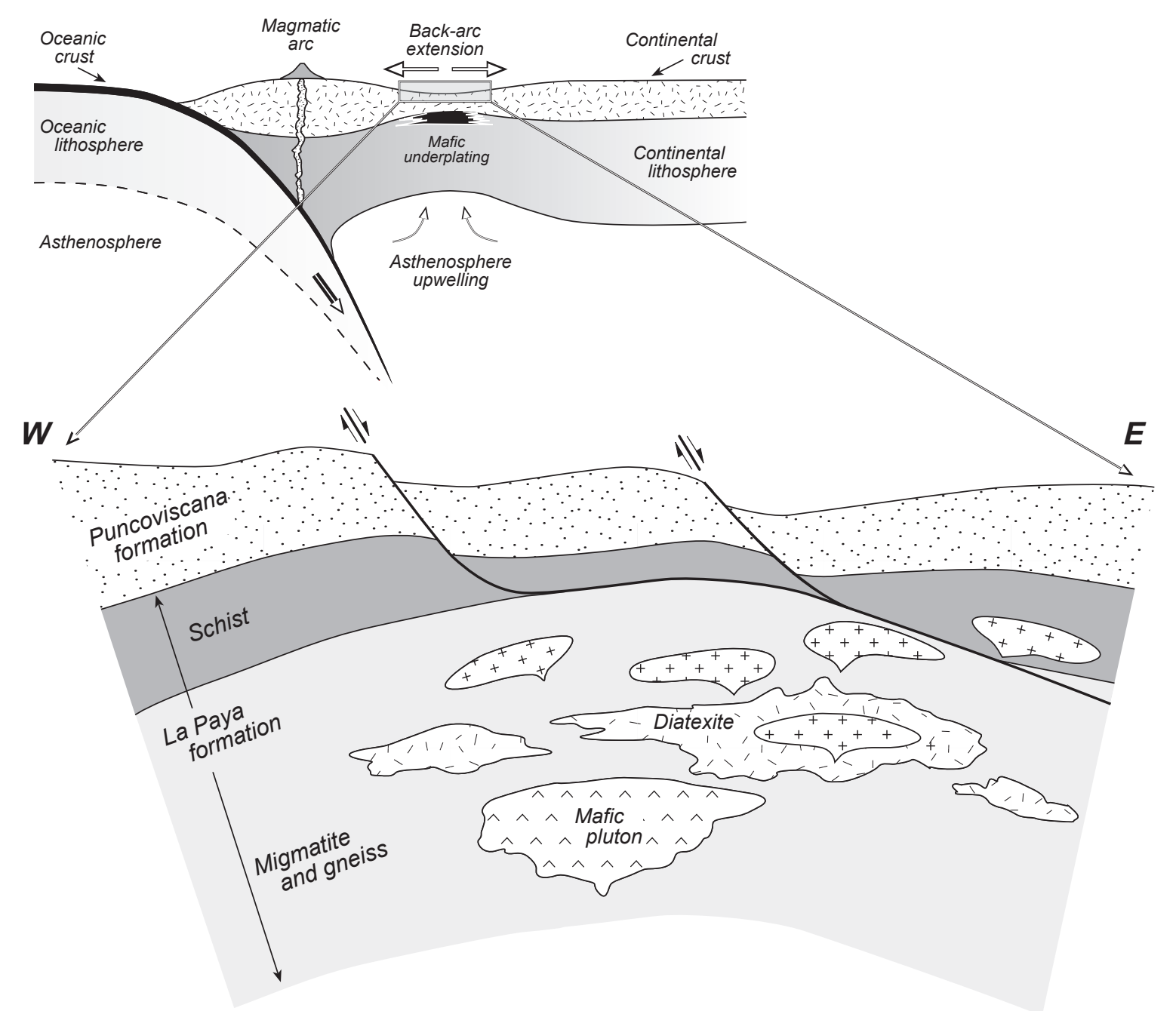

Fig. 10.- Schematic representation of the subduction-related retro-arc setting proposed in order to explain the synchronous development of HT-LP metamorphism, granite intrusions and gabbroic magmatism in the Cachi mountain ranges. The protoliths of the La Paya metamorphic formation corresponds to the older Puncoviscana Formation. The similar age of the metamorphic and plutonic rocks, around $477 \mathrm{Ma}$, links these processes to the Famatinian cycle.

ing at the base of the continental crust by huge amounts of mantle-derived magmas.

The sedimentation of the clastic sequences of the Puncoviscana Formation took place during the Ediacaran-Lower Cambrian according to the fossil content (soft bodies and traces) and the dominant cluster of ages on detrital zircons (Aceñolaza and Toselli, 2009; Hauser et al., 2011; Adams et al., 2011). The Mesón Group, of middle to upper Cambrian age (Moya, 2008; Astini, 2008; Augustsson et al., 2011), rests discordantly on the Puncoviscana Formation at several places along the Eastern Cordillera (Turner and Mon, 1979), which brackets the deformation of the Puncoviscana-type units to the upper early Cambrian - middle Cambrian. Ages of metamorphism by fine mica dating (Adams et al., 2008) and from granites intruding the Puncoviscana Formation at different sections of the Eastern Cordillera (Hongn et al., 2010; Hauser et al., 2011) confirm this oversimplified stratigraphic scheme. According to Lork et al. (1990), detrital zirconcores constrain an age of around $530 \mathrm{Ma}$ for the sedimentary source of the Puncoviscana Formation in the La Paya sector, which is supported by new analyses of detrital zircons indicating a maximum depositional age of 523 to $534 \mathrm{Ma}$ for these formations (Adams et al., 2011). In line with these results, the Tera-Wasserburg diagram for the U-Pb SHRIMP zircon-age data from the analyzed samples can be grouped in four clusters at around 477.5, 530.5, 573.7 and $658.5 \mathrm{Ma}$ (Fig. 8). The younger cluster marks the age of magmatism and metamorphism in the Cachi region and usually comes from zircon rims (Fig. 6; cathodoluminiscence images) while the older ones, from detrital zircon cores, represent the age of the sedimentary sources of the Puncoviscana and La Paya formations.

There is general agreement about the Early Ordovician age for the magmatism and metamorphic peaks in the Cachi region and neighbour areas (Lork et al., 1989; Lork y Bahlburg, 1993; Büttner et al., 2005; Haschke et al., 2005; Viramonte et al., 2007; Einhorn, 2010; Sola et al., 2010; Pearson et al., 2012), but discrepancies still subsist concerning the relation- 
ships between the magmatism and the metamorphism. The metamorphism of the la Paya Formation has been interpreted as a contact metamorphism promoted by the intrusion of trondhjemite plutons (Schön and Miller, 1990; Toselli, 1992; Méndez et al., 2006). The trondhjemite magmas are usually linked to the fusion of a mafic subducted slab or deep crust levels in the Famatinian arc zone (Galliski and Miller, 1989; Galliski et al., 1990; Méndez et al., 2006). According to this interpretation, the ascent of trondhjemitic magmas could produce a temperature increase sufficient to generate migmatite aureoles around the main trondhjemitic bodies. Alternatively, recent studies (Sola et al., 2010; Sola and Becchio, 2012) suggest that the pressure and temperature conditions reached during the Ordovician metamorphic peak can promote the generation of granite and trondhjemite melts from partial melting of Puncoviscana-type clastic sequences. These results imply a crustal origin for both, the granite and trondhjemitic plutons of the Cachi Formation. The field, petrographic and geochronological data presented in the previous sections of this work are consistent with the last interpretation.

With a few exceptions (Rossi et al., 1992; Büttner et al., 2005), the geological evolution of the Cachi ranges is related to a protracted contraction linked to a long lasting subduction event encompassing the Pampean and Famatinian orogenic cycles (Lucassen and Becchio 2003; Pearson et al., 2012). However, from the regional point of view and based mainly on stratigraphic analyses of the Ordovician basins, Bahlburg (1990), Balhburg and Hervé (1997), Astini (2008) and Coira et al. (2009), among others, proposed a Early Ordovician extensional back-arc followed by a contractional event from the Middle-Late Ordovician for the evolution of the Ordovician basins of the Central Andes (Ocloyic orogeny). In this regard, the structural evolution of the Sierra de Cachi, characterized by crustal extension associated with HT and LP metamorphism followed by a compressional event, is consistent with such a regional scenario. Consequently, we propose that the Sierra de Cachi, where coeval processes of extensional deformation, HT and LP metamorphism and acidic and basic magmatism coexist, meets the requirements to be interpreted as a retro-arc at mid levels of the continental crust (Fig. 10).

The heat source is a current issue of discussion in regions affected by HT-LP metamorphism (Wickham and Oxburgh, 1987; Escuder Viruete, 1999; White, 2005). From thermal modelling, Gerbi et al. (2006) conclude that the following mechanisms, operating alone, are able to induce anatexis in typical pelitic rocks: 1) Magmatic advection by pervasive flow, 2) Crustal-scale detachment faulting, and 3) The presence of a high-heat producing layer. We consider that in the Sierra de Cachi the temperature increase needed to promote anatexis of the metapelitic Puncoviscana Formation mainly reflects an isograde rise induced by high thermal flow, in response to a combination of thinning associated to the lithospheric extensional and probably to advection by magma underplating at the base of the tinned continental crust (Fig. 10).
Back-arc extension is frequently though as a side effect of subduction which is explained by three main driven mechanisms, referred to as the anchored slab model (Uyeda and Kanamori, 1979), the slab pull model (Chapple and Tullis, 1977) and the corner flow model (Sleep and Toksöz, 1971). Subduction roll-back, a variety of the slab pull model, followed of shallower subduction has been advocated as a possible mechanism for driving back-arc extension and subsequent contraction in the Andean belt (Astini, 2008). The alternation of extensional and compressional events imprinted in the La Paya Formation and in the plutons (granite and trondhjemite) of the Cachi Formation could be explained in this way and related to the Famatinian subduction along the western margin of Gondwana in Ordovician times.

\section{Acknowledgements}

We acknowledge the comments of U. Zimmermann and an anonymous reviewer. Finantial support by Spanish research projects CGL2010-14869 and CGL2011-23755 (Ministerio de Ciencia e Innovación), FEDER Funds of theEU and by the research group IT-364-10 (Gobierno Vasco) is also acknowledged.

\section{References}

Aceñolaza, F., Durand, F., Díaz Taddei, R. (1976): Geología y contenido paleontológico del basamento de la región de Cachi, Provincia de Salta, República Argentina. Actas $6^{\circ}$ Congreso Geológico Argentino, Bahía Blanca, T1, 319-332.

Aceñolaza, F.G., Toselli, A.J. (2009): The Pampean Orogen: EdiacaranLower Cambrian Evolutionary History of Central and Northwest Region of Argentina. In: C. Gaucher, A. Sial, G. Halverson and H. Frimmel (eds.), Neoproterozoic-cambrian tectonic, Global Change and Evolution: a focus on southwestern Gondwana. Development in Precambrian Geology 16, Elsevier, Amsterdam, pp. 239-254.

Adams, C.J., Miller, H., Toselli, A., Griffin, W.L. (2008): The Puncoviscana Formation of northwest Argentina: U-Pb geochronology of detrital zircons and $\mathrm{Rb}-\mathrm{Sr}$ metamorphic ages and their bearing on its stratigraphic age, sediment provenance and tectonic setting. Neues Jahrbuch für Geologie und Paläontologie Abhandlungen 247 (3), 341-352. doi: 10.1127/0077-7749/2008/0247-0341

Adams, C.J., Miller, H., Aceñolaza, F.G., Toselli, A., Griffin, W.L. (2011): The Pacific Gondwana margin in the late Neoproterozoicearly Paleozoic: Detrital zircon U-Pb ages from metasediments in northwest Argentina reveal their maximum age, provenance and tectonic setting. Gondwana Research 19 (1), 71-83. doi: 10.1016/j. gr.2010.05.002.

Astini, R. (2008): Sedimentación, facies, discordancias y evolución paleoambiental durante el Cámbrico-Ordovícico. In: B. Coira and E. Zappettini (eds.), Geología y Recursos Naturales de la Provincia de Jujuy. Relatorio 17th Congreso Geológico Argentino, Asociación Geológica Argentina, Jujuy, pp. 50-73.

Augustsson, C, Rüsing, T., Adams, C., Chmiel, H., Kocabayoğly, M., Büld, M., Zimmermann, U., Berndt, J., Kooijman, E. (2011): Detrital quartz and zircon combined: the production of mature sand with short transportation paths along the Cambrian West Gondwana margin, Northwestern Argentina. Journal of Sedimentary Research 81, 284298. doi: 10.2110/jsr.2011.23

Bachman, G., Grauert, B., Kramm, U., Lork, A., Miller, H. (1987): El 
magmatismo del Cámbrico medio/Cámbrico superior en el basamento del noroeste argentino: investigaciones isotópicas y geocronólogicas sobre los granitoides de los complejos intrusivos de Santa Rosa de Tastil y Cañaní. Actas 10 Congreso Geológico Argentino, Tucumán, vol. 4, pp. 125-127.

Bahlburg, H. (1990): The Ordovician basin in the Puna of NW Argentine and N Chile, geodynamic evolution from back-arc to foreland basin. Geotektonische Forschungen 75, 1-77.

Bahlburg, H., Hervé, F. (1997): Geodynamic evolution and tectonostratigraphic terranes of northwestern Argentina and northern Chile. Geological Society of America Bulletin 109, 869-884. doi: 10.1130/00167606(1997).

Basei, M.A.S., Siga Junior, O., Sato, K., Sproesser, W.M., 1995. A instalaçao da metodologia U-Pb na Universidade de Sao Paulo. Princípios metodológicos, aplicaçoes e resultados obtidos. An. Acad. Bras. Ciencias, 67, 221-236.

Black, L.P., Kamo, S.L., Allen, C.M., Aleinikoff, J.N., Davis, D.W., Korsch, R.J., Foudoulis, C. (2003): Temora 1: a new zircon standard for Phanerozoic U-Pb geochronology. Chemical Geology 200, 155170.

Büttner, S.H., Glodny, J., Lucassen, F., Wemmer, K., Erdmann, S., Handler, R., Franz, G. (2005): Ordovician metamorphism and plutonism in the Sierra de Quilmes metamorphic complex: Implications for the tectonic setting of the northern Sierras Pampeanas (NW Argentina). Lithos 83, 1-2, 143-181. doi: 10.1016/j.lithos.2005.01.06

Chapple W.M., Tullis T.E. (1977): Evaluation of the forces that drive the plates. Journal of Geophysical Research 82, 1967-1984. doi: 10.1029/JB082i014p01967.

Coira, B., Kirschbaum, A., Hongn, F., Pérez, B. Menegatti, N. (2009). Basic magmatism in northeastern Puna, Argentina: Chemical composition and tectonic setting in the Ordovician back-arc. Journal of South American Earth Sciences 28, 374-382. doi: 10.1016/j. jsames.2009.04.007.

Do Campo, M., Ribeiro Guevara, S. (2005): Provenance analysis and tectonic setting of late Neoproterozoic metasedimentary successions in NW Argentina. Journal of South American Earth Sciences 19, 143 153. doi: 10.1016/j.jsames.2005.01.003.

Einhorn, J. (2010): Geochronology of the Brealito basin, Northwestern Argentina. Geological Society of America, Abstracts with Programs 42 (5), Denver, p. 267.

Escayola, M.P., van Staal, C.R., Davis, W.J. (2011): The age and tectonic setting of the Puncoviscana Formation in northwestern Argentina: an accretionary complex related to Early Cambrian closure of the Puncoviscana Ocean and accretion of the Arequipa-Antofalla block. Journal of South American Earth Sciences 32 (4), 437-458. doi: 10.1016/j. jsames.2011.04.013.

Escuder Viruete, J. (1999): One- and two-dimensional thermal modeling of orogenic crustal extension in the Tormes Gneissic Dome, NW Iberian Massif, Spain. International Journal of Earth Sciences 88, 444 457. doi: 10.1007/s005310050277

Galliski, M.A. (1983a): Distrito minero El Quemado, departamento La Poma y Cachi, provincia de Salta; I, el basamento del tramo septentrional de la sierra de Cachi. Revista de la Asociación Geológica Argentina 38, 209-224.

Galliski, M.A. (1983b): Distrito minero El Quemado, departamentos La Poma y Cachi, Provincia de Salta: II, Geología de sus pegmatitas. Revista de la Asociación Geológica Argentina 38, 340-380.

Galliski, M.A., Miller, C. (1989): Petrogénesis de las trondhjemitas de Cachi: condicionamientos impuestos por elementos de Tierras Raras e implicancias tectónicas. Actas $1^{\circ}$ Reunión Geotransectas de América del Sur, Mar del Plata, pp. 58-62.

Galliski, M.A., Toselli, A.J., Saavedra, J. (1990): Petrology and geochemistry of the Cachi high-alumina trondhjemites, northwestern Argentina. In: S. m. Kay and C. W. Rapela (eds.), Plutonism from
Antarctica to Alaska, Geological Society of America, Special Paper 241, pp. 91-99.

Gerbi, C.C., Johnson, S.E., Koons, P.O. (2006): Controls on low-pressure anatexis. Journal of Metamorphic Geology 24, 107-118. doi:10. 1111/j.1525-1314.2005.00628.

Haschke, M., Deeken, A., Insel, N., Sobel, E., Grove, M., Schmitt, A. (2005): Growth pattern of the Andean Puna plateau constrained by apatite (U/Th)/He, K-feldspar 40Ar/39Ar, and zircon U-Pb geochronology. Proceedings 6th International Symposium on Andean Geodynamics (ISAG 2005), Barcelona, pp. 360-363.

Hauser, N., Matteini, M., Omarini, R.H., Pimentel, M.M. (2011): Combined $\mathrm{U}-\mathrm{Pb}$ and $\mathrm{Lu}-\mathrm{Hf}$ isotope data on turbidites of the Paleozoic basement of NW Argentina and petrology of associated igneous rocks: implications for the tectonic evolution of western Gondwana between 560 and 460 Ma. Gondwana Research 19, 100-127. doi: 10.1016/j.gr.2010.04.002.

Hongn, F., Aranguren, A., Tubía, J.M., Mon, R. (1999): Estructura, fábrica magnética y emplazamiento de los granitos de Brealito y La Paya, basamento del Valle Calchaquí, Salta, Argentina. In: F. Colombo, I. Queralt and I. Petrinovic (eds.), Geología de los Andes centrales meridionales: el noroeste Argentino. Acta Geológica Hispánica 34, pp. 301-317.

Hongn, F.D., Tubía, J.M., Aranguren, A., Vegas, N., Mon, R., Dunning, G.R. (2010): Magmatism coeval with Lower Paleozoic shelf basins in NWArgentina (Tastil Batholith): Constrains on current stratigraphic and tectonic interpretations. Journal of South American Earth Sciences 29, 289-305. doi: 10.1016/j.jsames.2009.07.008.

Jezek, P., Willner, A.P., Aceñolaza, F.G., Miller, H. (1985): The Puncoviscana trough: A large basin of Late Precambrian to Early Cambrian age on the Pacific edge of the Brazilian shield. Geologische Rundschau 74, 573-584. doi: 10.1007/BF01821213.

Keppie, J.D., Bahlburg, H. (1999): Puncoviscana Formation of northwestern and central Argentina: Passive margin or foreland basin deposit? In: Ramos, V.A. and Keppie, J.D. (eds.), Laurentia-Gondwana Connections before Pangea. Geological Society of America Special Paper 336, pp. 139-143.

Kraemer, P.E., Escayola, M.P., Martino, R.D. (1995): Hipótesis sobre la evolución tectónica Neoproterozoica de las Sierras Pampeanas de Córdoba $\left(30^{\circ} 40^{\prime}-32^{\circ} 40^{\prime}\right)$, Argentina. Revista de la Asociación Geológica Argentina 50, 47-59.

Larionov, A.N., Andreichev, V.A., Gee, D.G. (2004): The Vendian alkaline igneous suite of northern Timan: ion microprobe $\mathrm{U}-\mathrm{Pb}$ zircon ages of gabbros and syenite. In: D.G. Gee, V.L. Pease (eds.) The Neoproterozoic Timanide Orogen of Eastern Baltica, Memoirs of the Geological Society of London 30, pp. 69-74. doi: 10.1144/GSL. MEM.2004.030.01.07

Lork, A., Bahlburg, H. (1993): Precise U-Pb ages of Monazites from the Faja Eruptiva de la Puna Oriental, NW Argentina. Actas 12th Congreso Geológico Argentino y 2nd Congreso de Exploración de Hidrocarburos, Mendoza, T.4, pp. 1-6.

Lork, A., Miller, H., Kramm, U. (1989): U-Pb zircon and monazite ages of the La Angostura granite and the orogenic history of the northwest Argentine basement. Journal of South American Earth Sciences 2, 147-153. doi: 10.1016/0895-9811(89)90042-4

Lork, A., Miller, H., Kramm, H., Grauert, B. (1990): Sistemática U-Pb de zircones detríticos de la Formación Puncoviscana y su significado para la edad máxima de sedimentación en la sierra de Cachi (provincia de Salta), Argentina. In: F. Aceñolaza, H. Miller, A. Toselli (eds.), El Ciclo Pampeano en el noroeste argentino. INSUGEO-UNT, Serie Correlación Geológica 4, pp. 199-208.

Lucassen, F., Becchio, R. (2003): Timing of high-grade metamorphism: Early Paleozoic U-Pb formation ages of titanite indicate long-standing high-T conditions at the western margin of Gondwana (Argentina, $26^{\circ}-29^{\circ}$ S). Journal of Metamorphic Geology 21, 649-662. doi: 
10.1046/j.1525-1314.2003.00471.x.

Ludwig, K.R. (2003): User's Manual for Isoplot/Ex, Version 3.00, A Geochronological Toolkit for Microsoft Excel. Berkeley Geochronology Center Sp. Publ. Berkeley: 74 p.

Méndez, V., Nullo, F. E., Otamendi, J. (2006): Geoquímica de las Formaciones Puncoviscana y Cachi - Sierra de Cachi, Salta. Revista de la Asociación Geológica Argentina 61, 256-268.

Moya, C. (2008): El Paleozoico Inferior en el noroeste argentino. Evidencias, incógnitas, propuestas para la discusión. In: B. Coira and E. Zappettini (eds.), Geología y Recursos Naturales de la Provincia de Jujuy. Relatorio 17th Congreso Geológico Argentino, Asociación Geológica Argentina, Jujuy, pp. 74-84.

Mpodozis, C., Kay, S.M. (1999): Late Paleozoic to Triassic evolution of the Gondwana margin: Evidence from Chilean Frontal Cordilleran batholiths $\left(28^{\circ} \mathrm{S}\right.$ to $\left.38^{\circ} \mathrm{S}\right)$. Geological Society of America Bulletin 104(8), 999-1014. doi: 10.1130/0016-7606(1992)104.

Pearson, D. M., Kapp, P., Reiners, P. W., Gehrels, G. E., Ducea, M. N., Pullen, A., Otamendi, J. E., Alonso, R. N. (2012): Major Miocene exhumation by fault-propagation folding within a metamorphosed, early Paleozoic thrust belt: Northwestern Argentina. Tectonics 31, TC4023. doi:10.1029/2011TC003043.

Rapela, C. (1976): Las rocas granitoides de la región de Cafayate, provincia de Salta. Aspectos petrológicos y geoquímicos. Revista de la Asociación Geológica Argentina 31 (4), 260-271.

Rossi, J. N., Toselli, A. J., Durand, F. R. (1992): Metamorfismo de baja presión, su relación con el desarrollo de la cuenca Puncoviscana, plutonismo y régimen tectónico. Argentina. Estudios Geológicos 48, 279-287.

Scheuber, E., Reutter, K.J. (1992): Magmatic arc tectonics in the Central Andes between $21^{\circ}$ and $25^{\circ}$ S. Tectonophysics 205 (1-3), 127-140. doi: 10.1016/0040-1951(92)90422-3.

Schön, C., Miller, H. (1990): The evolution of the Lower Paleozoic trondhjemite/granite suites SW of Cachi, NW-Argentina. Symposium International Géodynamique Andine. Colloques et Séminaires, Grenoble, France, pp. 363-366.

Sleep N., Toksöz M. (1971): Evolution of marginal basins. Nature 33, 548-550. doi: 10.1038/233548a0.

Sola, A.M., Becchio, R.A. (2012): Distribución de elementos traza y grado de fusión parcial en migmatitas de la sierra de Molinos, Salta. Revista de la Asociación Geológica Argentina 69, 240-251.

Sola, A.M., Becchio, R.A., Pimentel, M.M. (2010): Leucogranito Pumayaco: anatexis cortical durante el ciclo orogénico Famatiniano en el extremo norte de la Sierra de Molinos, provincia de Salta. Revista de la Asociación Geológica Argentina 66, 206-224.

Stacey, S., Kramers, J.D. (1975): Approximation of terrestrial lead isotope evolution by a two-stage model. Earth Planetary Science Letters 26, 207-221.

Steiger, R.H., Jäger, E. (1977): Subcommission on geochronology: convention on the use of decay constants in geo- and cosmochronology. Earth Planetary Science Letters 36, 359-362.
Toselli, A. (1992): El magmatismo del noroeste argentino. Universidad Nacional de Tucumán, Serie Correlación Geológica 8: 243 p.

Toselli, A., Rossi, J., Rapela, C. (1978): El basamento metamórfico de la sierra de Quilmes, República Argentina. Revista de la Asociación Geológica Argentina 33 (2), 105-121.

Tubía, J.M., Hongn, F., Aranguren, A. (2005): Positive inversion tectonics in the Precambrian basement of the Nevado de Cachi mountains (Salta, Argentina). In: R. Pankhurst, R. and G. Veiga G. (eds.), Gondwana 12 Abstracts. Academia Nacional de Ciencias, Mendoza, p. 354.

Tubía, J.M., Hongn, F., Aranguren, A. (2008): Inversión tectónica en la corteza dúctil: basamento neoproterozoico-paleozoico inferior de la sierra de Cachi (Salta). Actas $17^{\text {th }}$ Congreso Geológico Argentino, Jujuy, T1, pp. 55-56.

Turner, J.C. (1964): Descripción Geológica de la Hoja 7c (Nevado de Cachi). Dirección Nacional de Geología y Minería, Boletín 99, 78 p.

Turner, J.C., Mon, R. (1979): Cordillera Oriental. In: Turner, J.C. (ed.), $2^{\circ}$ Simposio de Geología Regional Argentina 2, Academia Nacional de Ciencias, Córdoba, pp. 57-94.

Uyeda S., Kanamori H. (1979): Back-arc opening and mode of subduction. Journal of Geophysical Research 84, 1049-1061. doi: 10.1029/ JB084iB03p01049

Viramonte, J.M., Becchio, R.A., Viramonte, J.G., Pimentel, M.M., Martino, R.D. (2007): Ordovician igneous and metamorphic units in southeastern Puna: New U-Pb and Sm-Nd data and implications for the evolution of northwestern Argentina. Journal of South American Earth Sciences 24, 167-183. doi: 10.1016/j.jsames.2007.05.005.

White, D. J. (2005): High-temperature, low-pressure metamorphism in the Kisseynew domain, Trans-Hudson orogen: crustal anatexis due to tectonic thickening? Canadian Journal of Earth Sciences 42, 707 721. doi: 10.1139/E04-087.

Wickham, S.M., Oxburgh, E.R. (1987): Low-pressure regional metamorphims in the Pyrenees and its implications for the thermal evolution of rifted continental crust. Philosophical Transactions of the Royal Society of London 321, 219-242.

Wiedenbeck, M., Allé, P., Corfu, F., Griffin, W.L., Meier, M., Oberli, F., Quadt, A., Von Roddick J.C., Spiegel, W. (1995): Three natural zircon standards for $\mathrm{U}-\mathrm{Th}-\mathrm{Pb}, \mathrm{Lu}-\mathrm{Hf}$, trace elements and REE analyses. Geostandards and Geoanalytical Research 19, 1-23. doi: 10.1111/j.1751-908X.1995.tb00147.x

Williams, I.S. (1998): Chapter 1: U-Th-Pb geochronology by ion microprobe. In: M.A. McKibben, W.C. Shanks III and W.I. Ridley (eds.). Applications of Microanalytical Techniques to Understanding Mineralizing Processes. Reviews in Economic Geology 7, pp. 1-35.

Zimmermann, U. (2005). Provenance studies of very low to low-grade metasedimentary rocks of the Puncoviscana Complex, northwest Argentina. In: Vaughan, A.P.M.; Leat, P.T.; Pankhurst, R.J. (eds): Terrane Processes at the margins of Gondwana Geological Society London, Special Publications 246, pp. 381-416.

Zimmermann, U., Niemeyer, H., Meffre, S. (2010): Revealing the continental margin of Gondwana: the Ordovician arc of the Cordón de Lila (northern Chile). International Journal of Earth Sciences 99 (Suppl 1), S39-S56. doi: 10.1007/s00531-009-0483-8. 